\title{
Oxidation behavior of a glass-based composite coating with a low expansion cermet bond-coat and an AIN diffusion barrier on K417G superalloy
}

DOI:

10.1016/j.corsci.2018.10.001

\section{Document Version}

Accepted author manuscript

Link to publication record in Manchester Research Explorer

Citation for published version (APA):

Wang, X., Zhu, S., Li, Z., Chang, L., Wu, Q., Zhang, Y., \& Wang, F. (2018). Oxidation behavior of a glass-based composite coating with a low expansion cermet bond-coat and an AIN diffusion barrier on K417G superalloy. Corrosion Science, 145, 283-294. https://doi.org/10.1016/j.corsci.2018.10.001

Published in:

Corrosion Science

\section{Citing this paper}

Please note that where the full-text provided on Manchester Research Explorer is the Author Accepted Manuscript or Proof version this may differ from the final Published version. If citing, it is advised that you check and use the publisher's definitive version.

\section{General rights}

Copyright and moral rights for the publications made accessible in the Research Explorer are retained by the authors and/or other copyright owners and it is a condition of accessing publications that users recognise and abide by the legal requirements associated with these rights.

\section{Takedown policy}

If you believe that this document breaches copyright please refer to the University of Manchester's Takedown Procedures [http://man.ac.uk/04Y6Bo] or contact uml.scholarlycommunications@manchester.ac.uk providing relevant details, so we can investigate your claim.

\section{OPEN ACCESS}




\title{
Oxidation behavior of a glass-based composite coating with a low expansion cermet bond-coat and an AIN diffusion barrier on K417G superalloy
}

Xin Wang ${ }^{1}$, Shenglong $\mathrm{Zhu}^{2}$, Zhengxian $\mathrm{Li}^{1}$, Litao Chang ${ }^{3}$, Qing $\mathrm{Wu}^{4}$, Yusheng Zhang ${ }^{1}$,

Fuhui Wang ${ }^{2}$

${ }^{1}$ Northwest Institute for Non-Ferrous Metal Research, Xi' an 710016, China

${ }^{2}$ Institute of Metal Research, Chinese Academy of Sciences, Shenyang 110016, China

${ }^{3}$ Materials Performance Center, The Unversity of Manchester, Manchester, UK M13 9PL

${ }^{4}$ School of Materials Science and Engineering, Shaanxi University of Science and Technology, Xi'an 710021, China

*Corresponding author: Tel: +86-29-86283410; Fax: +86-29-86231103; E-mail address: wangx@alum.imr.ac.cn.

\begin{abstract}
A ceramic particle reinforced glass matrix composite coating with a novel $\mathrm{Ni}+\mathrm{CrAlYSiN}$ cermet bond-coat and an AlN diffusion barrier was prepared on $\mathrm{K} 417 \mathrm{G}$ superalloy, and its oxidation behavior at $1000{ }^{\circ} \mathrm{C}$ was investigated. The results indicated that the oxidation rate of the coating was significantly reduced compared to the standalone coating, because the glass too-coat promoted selectively oxidation of $\mathrm{Al}$ within the bond-coat due to the oxygen barrier effect. The cyclic oxidation resistance of the coating was improved as well, due to the reduction of the thermal expansion misfit and the reduced inter-diffusion the bond-coat and the substrate.
\end{abstract}

Keywords: A. glass; A. superalloys; C. oxidation. 


\section{Introduction}

Oxidation resistant coatings are widely applied to the metallic components which work in oxidizing environments to ensure their reliability. Traditionally, these coatings can be categorized into two types based on their protecting mechanisms. The first type is the ones which form and maintain a protective oxide scale, usually the chromia, alumina and silica [1-4], when they are exposed to oxidizing environments. The second type is inert oxide coatings which have low oxygen permeability at high temperatures and also superior adhesion with the substrates. This type of coatings is proved to be effective and more economic than the first type. Aluminide, overlay $\mathrm{MCrAlY}(\mathrm{M}=\mathrm{Ni}, \mathrm{Co}$, or $\mathrm{NiCo})$, and silicides are typical type one coatings, whilst ceramic [5-7], glass [8-12], glass-ceramic [13-15] or glass-metal ones [16-18] belong to the second type. Recently, the glass-based composite coatings have attracted lots of attentions because they exhibit excellent oxidation resistance on a range of materials. These materials include stainless steel [10,11], Ti-based alloys [12], TiAl intermetallics [13], superalloys [14-18], refractory alloys [19] and carbon/carbon (C/C) composites [20].

However, challenging issues still remain to be solved for the high temperature application of these glass-based composite coatings. The most serious one among them is that these coatings are prone to crack and peel off from the substrates during cyclic oxidation because of the large thermal expansion coefficient (CTE) mismatch between the coatings and the metallic substrates. Efforts, such as modifying the component design [9] and pre-crystallization [21], have been done to increase the CTE of the glass matrix; however, the result is still not satisfactory. Adding particles of metal $[16-18,22,23]$ or oxides [12,18,21-24] with higher CTEs into the glass matrix has been tried as well. Although this method improves the cyclic oxidation resistance of the coating, problems are brought into the coating system at the same time. In fact, the metallic additions can be quickly oxidized when oxygen penetrated in the coating $[17,18]$. Moreover, interfacial reactions usually occur between the base glass and the oxides, which are either added deliberately $[25,26]$ or introduced by oxidation of metallic additions $[17,18]$. These reactions generally lead to the degradation of composite coatings and then deteriorate their performance.

According to the designing logistics of the thermal barrier coatings (TBCs), introducing a bond-coat between the glass-based coating and the metallic substrate might be a promising way, which can mitigate the CTE mismatch problem and in turn improve the cyclic oxidation resistance of the coating. Nevertheless, due to their higher CTEs than 
that of the glass matrix (usually below $10 \times 10^{-60} \mathrm{C}^{-1}$ [29]), the widely used aluminide $\left(\sim 15 \times 10^{-6}{ }^{\circ} \mathrm{C}^{-1}[27]\right)$ and MCrAlY $\left(16-20 \times 10^{-6}{ }^{\circ} \mathrm{C}^{-1}[27,28]\right)$ bond-coats in TBCs are evidently not suitable for the glass-based coatings, because their CTEs are still much larger.

In this investigation, a nanocrystalline $\mathrm{Ni}+\mathrm{CrAlYSiN}$ cermet bond-coat was introduced to a bi-layered $\mathrm{SiO}_{2}-\mathrm{Al}_{2} \mathrm{O}_{3}-\mathrm{ZrO}_{2}-\mathrm{TiO}_{2}$-based glass coating for a $\mathrm{K} 417 \mathrm{G}$ Ni-based superalloy; and the oxidation behaviour, especially the cyclic oxidation, together with the mircrostructural evolution of the coating during oxidation was investigated. The effect of interfacial reactions on TGO development of the $\mathrm{Ni}+\mathrm{CrAlYSiN}$ bond-coat was discussed as well. The CTE of this Ni+CrAlYSiN cermet bond-coat was estimated to be $12.6 \times 10^{-6}{ }^{\circ} \mathrm{C}^{-1}$ according to the Turner equation [30], and it is much lower than that of MCrAlY, aluminide, and Ni-based superalloys $\left(\sim 18 \times 10^{-6}\right.$ $\left.{ }^{\circ} \mathrm{C}^{-1}[31]\right)$. Thus, it can be expected that application of this $\mathrm{Ni}+\mathrm{CrAlYSiN}$ cermet could reduce the CTE mismatch between the glass-based composite coating and the underlying superalloy substrate, and then improve the cyclic oxidation resistance. Moreover, corundum and YSZ (8wt.\% yittria stabilized zirconia) particles were added into the glass matrixin in order to control the crystallization behavior of the glass matrix [25], increase the CTE and stabilize the coating [21].

\section{Experimental procedures}

\subsection{Materials}

The glass frit with composition shown in Table I was used for the preparation of the glass coating and the details of how it was prepared are available at ref. [25]. These frit granules were further processed by two steps to refine the particle size. The first step was to mill them using an agate jar and balls for $100 \mathrm{~h}$, and the particle size was reduced to less than $10 \mu \mathrm{m}$. The second step was to ball mill the particles obtained from the first stein an agate container with ethanol media, which further reduced the particle size to less than $5 \mu \mathrm{m}$. The dispersed oxides were commercially available $99 \mathrm{wt} . \%$ corundum with mean size of about $1 \mu \mathrm{m}$ (Shenyang Reagent Factory, Shenyang, China) and YSZ (HuaGongZhiYuan Co., Wuhan, China) with size less than $5 \mu \mathrm{m}$.

The chemistry of the nickel-based superalloy $\mathrm{K} 417 \mathrm{G}$ used in this study is listed in Table II. Coupons with dimensions of $20 \mathrm{~mm} \times 10 \mathrm{~mm} \times 2.5 \mathrm{~mm}$ were extracted from the as-received block, and successively ground up to 2000-grit SiC paper, polished with diamond paste $(1.5 \mu \mathrm{m})$, ultrasonically cleaned within ethanol and acetone and then sputter-cleaned for $3 \mathrm{~min}$ to remove any possible contaminants before the coating 
process..

Cathode Al with purity of $99.99 \%$ and NiCrAlYSi targets with compositions of $\mathrm{Ni}-21 \mathrm{Cr}-10 \mathrm{Al}-0.5 \mathrm{Si}-0.5 \mathrm{Y}$ (wt.\%) were used for the preparation of the coatings.

\subsection{Coating preparation}

An AlN diffusion barrier and a Ni+CrAlYSiN cermet bond-coat (denoted as BC in figures) was coated on the substrate material via serial depositions using $\mathrm{Al}$ and NiCrAlYSi targets prior to the preparation of the bi-layered glass-based composite top-coat (denoted as TC in figures). The AlN diffusion barrier was deposited to the substrate through filtered arc ion plating (AIP) which could avoid the introducing of droplets during vacuum arc evaporation, and the thickness of the AlN diffusion barrier was controlled to be $\sim 400 \mathrm{~nm}$. During deposition, $\mathrm{N}_{2}$ (99.99\%) and Ar (99.99\%) were introduced into the chamber using two independent mass-flow controllers, and the total pressure of the argon-nitrogen mixture was controlled to be equal to or lager than $0.2 \mathrm{~Pa}$. Typical deposition parameters for these processes can be found in Table III. The $\mathrm{Ni}+\mathrm{CrAlYSiN}$ composite cermet was prepared by arc ion plating under a vacuum of $6 \times 10^{-3} \mathrm{~Pa}$. The thickness of this coating was controlled to be $\sim 20 \mu \mathrm{m}$, and it is also worth to mention that this coating had a nanocrystalline structure.

The bi-layered glass-based composite top-coat was prepared on the coupons which were already deposited with $\mathrm{AlN}$ and $\mathrm{Ni}+\mathrm{CrAlYSiN}$ composite cermet through sintering, which consisted of three steps. Step 1 was to prepare two kinds of slurries, achieved by wet-blending the glass powders with inclusions with various ratios within an agate container for $2 \mathrm{~h}$. The particle to alcohol ratio was about $10 \mathrm{~g}$ : $160 \mathrm{~mL}$. The ratio of corundum: YSZ: glass for the under-layer was about 17: 5: 78, whilst it was about 10: 25: 65 for the upper-layer. Step 2 was to prepare the under-layer ( $\sim 30 \mu \mathrm{m}$ thick), achieved by sintering the glass-inclusions-ethanol slurries that were air-sprayed on the coupons under a selected condition, and the coupons were cooled in air when the sintering had finished. Step 3 was to prepare the upper-layer $(\sim 100 \mu \mathrm{m})$, also achieved through sintering. The typical parameters for these processes are shown in Table IV.

\subsection{Oxidation test}

These coated coupons were then placed in alumina crucibles and placed in a muffle furnace for isothermal oxidation tests, the oxidation temperature was selected at $1000{ }^{\circ} \mathrm{C}$ and there was no air flew in and out during the tests. These alumina crucibles were all heat-treated in a furnace at $1200{ }^{\circ} \mathrm{C}$ for $24 \mathrm{~h}$ to ensure that their weight would not change during the tests. The coupons were taken out from the furnace at specific time intervals 
and cooled in air for mass measurement. Their weight change together with the alumina crucibles was recorded using an electronic balance with sensitivity of $10^{-5} \mathrm{~g}$ (Sartorius BP211D), which ensured that the spalled scale was included. The mean mass gains were calculatedfrom five parallel specimens.

Cyclic oxidation test was conducted at $1000{ }^{\circ} \mathrm{C}$ in static air for 100 cycles using a muffle furnace as well. The duration for each cycle was $1 \mathrm{~h}$, and the coupons were taken out from the furnace, cooled down to room temperature within $10 \mathrm{~min}$. and weighed when specific cycles had finished. Five parallel specimens were measured for each test as well. Coupons with the standalone $\mathrm{Ni}+\mathrm{CrAlYSiN}$ cermet coating and the AlN diffusion barrier were also oxidized under the same condition for comparison.

\subsection{Characterization}

X-Ray diffraction (XRD, Panalytical X' Pert PRO, $\mathrm{CuK \alpha}$ radiation at $40 \mathrm{kV}$, PANalytical, Almelo, Holland) was used to characterize the phase constitutions of the coating. Scanning electron microscopy (SEM, Inspect F50, FEI Co., Hillsboro, OR) equipped with an energy dispersive X-ray spectrometer (EDS, X-Max, Oxford Instruments Co., Oxford, U.K.) was used to characterize the surface and cross-sectional morphologies of the coating. Electron probe microanalysis (EPMA-1610, Shimadzu, Kyoto, Japan) was used to determine the elemental distribution.

\section{Results}

\subsection{Microstructure of the as-prepared coating}

Figure 1 shows the indexed XRD pattern of the as-prepared glass-based composite coating. Diffraction peaks of three phases were indexed from the pattern, and they were YSZ, zircon and gahnite, respectively. Evidently, YSZ corresponded to the added YSZ particles; whilst the formation of zircon (nominally $\mathrm{ZrSiO}_{4}$ ) was possibly caused by the interfacial reactions between the YSZ particles and the glass matrix. This was consistent with our previous study [25]. Weak diffraction peaks of gahnite (nominally $\mathrm{ZnAl}_{2} \mathrm{O}_{4}$ ) instead of corundum were detected, suggesting that the added corundum particles at the surface of the upper-layer had already dissolved into the base glass and further reacted with the glass matrix.

Figure 2A and B show the appearance of the coated specimens and a secondary electron image taken on the surface of the composite coating, respectively. It can be seen that the surface of the composite coating was very smooth without any protuberances. Cross-sectional examination was carried out to see the structure of the coating in detail, and the result is shown in Figure 2C. As expected, a bi-layer structured composite 
top-coat formed on the superalloy substrate, which can be evidenced by the different contrast between the under-layer and the upper-layer, caused by the various contents of incorporated oxides (YSZ and corundum). Some pores were also observed within the top-coat (arrowed in Figure 2C), indicating that some gases were trapped in the top-coat during sintering. Beneath the glass-based composite top-coat was the Ni+CrAlYSiN composite bond-coat, which has a thickness of $\sim 20 \mu \mathrm{m}$. The Ni+CrAlYSiN coating was composed of metallic nanocrystalline $\gamma-\mathrm{Ni}(\mathrm{CrAlYSi})$ and the embedded $\mathrm{AlN}$ and $\mathrm{CrN}$ particles. The volume fractions for these three constituents were $62 \mathrm{vol} . \%, 12 \mathrm{vol} . \%$ and 26vol.\%, respectively [30]. The details of the characterization of the Ni+CrAlYSiN composite bond-coat can be found in the studies of Zhu et al [30,32]. Figure 2C also shows the interface between the top-coat and the underlying bond-coat, and no pores or cracks were observed at the interface, which indicated that they adhered very well with each other. In addition, interdiffusion between the bond-coat and the superalloy substrate was not apparent after the sintering process of the glass-based top-coat because of the AlN diffusion barrier.

Figure 3 shows the cross-sectional back-scattered electron (BSE) image and the corresponding EPMA elemental maps of the as-prepared coated specimens. The distribution of specific phases can be identified based on the distribution of the individual elements which they were enriched in. The Zr-related phases (YSZ and zircon) were across the cross section of the coating, which can be evidenced by the Zr map in Figure 3B; whilst the Al-related phases (corundum and gahnite) were aggregated at the top-coat/bond-coat interface, evidenced by the Al map. Besides, the Al content in the under-layer was much higher than that in the upper-layer because of the larger corundum additions. However, the aggregation of $\mathrm{Zn}$ within the top-coat was not apparent although gahnite was identified in the XRD pattern, as shown in Figure 3E. According to the elemental distribution of $\mathrm{Ni}$ and $\mathrm{Ti}$ in Figure $3 \mathrm{E}$ and $3 \mathrm{~F}$, it is clear that their diffusion towards the top-coat was not obvious.

\subsection{Isothermal oxidation behavior and kinetics}

Figure 4Ashows the isothermal oxidation kinetics of the pure $\mathrm{Ni}+\mathrm{CrAlYSiN}$ cermet coating and the bi-layer structured glass-based composite coating with $\mathrm{Ni}+\mathrm{CrAlYSiN}$ bond-coat and AlN diffusion barrier at $1000{ }^{\circ} \mathrm{C}$. These curves show the oxidation of both coatings followed a parabolic law, although the weight gain rates for the bi-layer structured glass-based composite coating was much smaller than that of the pure $\mathrm{Ni}+\mathrm{CrAlYSiN}$ cermet coating. The parabolic oxidation rate constant for the 
$\mathrm{Ni}+\mathrm{CrAlYSiN}$ coating with the glass-based composite top-coatwas $2.53 \times 10^{-14} \mathrm{~g}^{2} \mathrm{~cm}^{-4} \mathrm{~s}^{-1}$; and the oxidation rate experienced a sharp decrease when the exposure duration was larger than $40 \mathrm{~h}$. For the pure Ni+CrAlYSiN coating, the parabolic oxidation rate constants were $1.24 \times 10^{-12} \mathrm{~g}^{2} \mathrm{~cm}^{-4} \mathrm{~s}^{-1}$ and $2.62 \times 10^{-13} \mathrm{~g}^{2} \mathrm{~cm}^{-4} \mathrm{~s}^{-1}$ before and after oxidation for $10 \mathrm{~h}$, respectively. This is similar to the results reported by Ren et al [33]. The higher oxidation rate of the pure $\mathrm{Ni}+\mathrm{CrAlYSiN}$ coating was probably caused by the growth of transient oxide $\mathrm{Ni}(\mathrm{Cr}, \mathrm{Al})_{2} \mathrm{O}_{4}[30]$.

Figure 5 shows the XRD pattern of the glass-based composite coating with a cermet bond-coat after isothermal oxidation at $1000{ }^{\circ} \mathrm{C}$ for $100 \mathrm{~h}$. Weaker diffraction peaks associated with YSZ and stronger diffraction peaks associated with zircon presented on the pattern compared with that for the coating before the oxidation (Figure 1). This indicates that interfacial reactions happened between YSZ and the base glass. Besides gahnite, a new precipitate of albite (nominally $\mathrm{NaAlSi}_{3} \mathrm{O}_{8}$ ) was indexed from the XRD pattern as well. Our previous study showed that albite is less thermodynamically stable than gahnite at $1000{ }^{\circ} \mathrm{C}$, and it can only precipitate when $\mathrm{Al}^{3+}$ is over saturated in the base glass [21]. So the precipitation of the albite is possibly because the added corundum dissolved during oxidation and led to the saturation of the base glass with $\mathrm{Al}^{3+}$.

Figure 6 shows the plan-view and the cross-section view of the glass-based composite coating after isothermal oxidation at $1000{ }^{\circ} \mathrm{C}$ for $100 \mathrm{~h}$. Surface of the composite coating kept smooth after oxidation, as shown in Figure 6A; whilst both the size and amount of the bubbles in the as-prepared top-coat changed during the test, as shown in Figure 6B. The number of the bubbles decreased while the size increased, and this is possibly caused by the aggregation of trapped bubbles during oxidation. Figure 6C shows the microstructure of the composite near the bond-coat, and it can be seen that interdiffusion between the bond-coat and the $\mathrm{K} 417 \mathrm{G}$ superalloy substrate was restrained because of the introducing of the AIN diffusion barrier. Figure 7A and 7B show the microstructures of the bond-coat/TGO/top-coat interface after oxidation at $1000{ }^{\circ} \mathrm{C}$ for 40 $\mathrm{h}$ and $100 \mathrm{~h}$, respectively. It is very clear as arrowed that a continuous new phase formed at the bond-coat/top-coat interface. This new phase was confirmed to be $\alpha-\mathrm{Al}_{2} \mathrm{O}_{3}$ based on the result shown in our previous study [26]. It is also worth saying that this $\alpha-\mathrm{Al}_{2} \mathrm{O}_{3}$ layer thickened very slowly with the oxidation time prolonged from $40 \mathrm{~h}$ to $100 \mathrm{~h}$ and it is coincident with the oxidation kinetics of the coating (Figure 4).

Figure 8 shows the BSE image and elemental distribution maps of the cross section of the coated specimen after oxidation at $1000{ }^{\circ} \mathrm{C}$ for $100 \mathrm{~h}$. The distribution of $\mathrm{Zr}$ was 
similar to that in Figure 3B, as shown in Figure 8B. Figure 8C provided solid evidence of the formation of $\alpha-\mathrm{Al}_{2} \mathrm{O}_{3}$ because $\mathrm{Al}$ aggregated at the bond-coat/top-coat interface. Moreover, selective oxidation of $\mathrm{Al}$ within the $\mathrm{Ni}+\mathrm{CrAlYSiN}$ bond-coat during oxidation resulted in an Al-depletion zone beneath the $\alpha-\mathrm{Al}_{2} \mathrm{O}_{3}$ scale as shown in Figure $8 \mathrm{C}$, which is consistent with the observation in Figure 6C. Zn enriched zones were also observed, as shown in Figure 8D. These zones were further judged to be gahnite, which precipitated within the top-coat during oxidation, as it was already confirmed to present in the coating through XRD (Figure 5). Except the formation of tiny amount of Ti-rich phases appeared at the diffusion barrier/substrate interface, no observable change was observed for the distribution of $\mathrm{Ni}$ and $\mathrm{Ti}$ during the oxidation process, as can be seen from Figure 8E and $8 \mathrm{~F}$. This was probably caused by interfacial reactions between the AlN diffusion barrier and the element of Ti within the $\mathrm{K} 417 \mathrm{G}$ superalloy substrate.

\subsection{Cyclic oxidation behavior and microstructure evolution}

Figure 9A and Figure 9B show the appearance of bi-layer structured glass-based composite coating with the Ni+CrAlYSiN bond-coat after 100 times cyclic oxidation and the associated oxidation kinetics, respectively. Figure 9A shows that the glass-based composite coating kept intact except spall at the edge of the specimen. The mass loss of the glass-based composite coating was not apparent within the first 20 thermal cycles, while it became very clear with increasing cyclic times. The surface morphology and cross-sectional microstructure of the glass-based composite coating with the $\mathrm{Ni}+\mathrm{CrAlYSiN}$ bond-coat was very similar to those in Figure $6 \mathrm{~A}$ and $6 \mathrm{~B}$, and were not shown here for concision. For comparison, cyclic oxidation kinetics of the standalone $\mathrm{Ni}+\mathrm{CrAlYSiN}$ coating was reported, and its mass change was $0.65 \mathrm{mg} \mathrm{cm}^{-2}$ after cyclic oxidation for 100 times.

Figure $10 \mathrm{~A}$ and $10 \mathrm{~B}$ show the microstructures of the inner part of the top-coat before and after cyclic oxidation for 100 times at $1000{ }^{\circ} \mathrm{C}$, respectively. It is very clear in Figure $10 \mathrm{~A}$ that a very thin layer of gahnite formed around the corundum particles, while the reaction products between the YSZ additions and the base glass was not obvious. However, as shown in Figure 10B, the incorporated corundum transformed into gahnite, and this was consistent with the XRD results in Figure 6, where diffraction peaks of corundum were not obvious. Moreover, zircon formed around the YSZ additions, the formation and growth process of which can be found in detail within our previous study [25]. The direct influence of the degradation of the top-coat is that it changed the thermal expansion behavior of the top-coat, and this will be discussed in the following part. 


\section{Discussion}

\subsection{Effect of the glass-based composite top-coat on isothermal oxidation behavior of the}

$\mathrm{Ni}+\mathrm{Cr}$ AlYSiN cermet bond-coat

The K417G superalloy which was used in the present investigation has low Al (5.25wt\%) and $\mathrm{Cr}(9.0 \mathrm{wt} \%)$ contents, and it always suffers with catastrophic oxidation when oxidized at high temperature. This is because the oxides (especially $\mathrm{MoO}_{3}$ ) formed on it has little protectiveness because it was mainly composed of an outer $\mathrm{NiO}$ layer, an intermediate $\mathrm{NiTiO}_{3}$ layer mixed with trace $\mathrm{CoCr}_{2} \mathrm{O}_{4}$ and $\mathrm{TiO}_{2}$, and a discontinuous $\mathrm{Al}_{2} \mathrm{O}_{3}$ inner layer [34]. Application of the $\mathrm{Ni}+\mathrm{CrAlYSiN}$ nanocrystalline coating significantly improves the oxidation resistance of the $\mathrm{K} 417 \mathrm{G}$ superalloy due to the formation of an exclusive $\alpha-\mathrm{Al}_{2} \mathrm{O}_{3}$ scale. As is well accepted, alumina is the priority choice for coatings against high temperature oxidation because of its much slower growth rate than chromia and other oxides [35]. In fact, a critical amount of Al is always added to the coating in order to promote the nucleation and growth of a continuous alumina. Besides, Cr also contributes to the formation of a continuous external alumina scale, since Cr "getters" oxygen and lowers the oxygen solubility in the alloy, allowing alumina to form at lower $\mathrm{Al}$ activities (contents) [36,37]. However, the activities of $\mathrm{Al}$ and $\mathrm{Cr}$ within the NiCrAlYSi coating is always lower than what they should be because they formed of AlN and $\mathrm{CrN}$ during the nitridation process. Thus, the alumina forming ability of the bond-coat was weakened, although the nitridation process was beneficial for lowering the CTE mismatch between the coating and the substrate.

Nevertheless, it is of interest that the mass increment of the Ni+CrAlYSiN cermet coating $\left(0.38 \mathrm{mg} \mathrm{cm}^{-2}\right)$ after oxidation at $1000{ }^{\circ} \mathrm{C}$ for $100 \mathrm{~h}$ was much smaller than that of the NiCrAlYSi coating prepared by AIP $\left(0.61 \mathrm{mg} \mathrm{cm}^{-2}\right)$ [32]. The slower oxidation rate of $\mathrm{Ni}+\mathrm{CrAlYSiN}$ cermet nanocomposite coating is attributed to the reduced diffusivity of $\mathrm{Y}$ within the cermet coating. As is well known, reactive elements can block the short circuit diffusion paths in the oxide scale and prohibit segregation of sulphur and other impurities at the metal/oxide interface $[38,39]$. Although addition of a combination of $\mathrm{Y}$ and $\mathrm{Hf}$ or $\mathrm{Zr}$ is better for the performance of $\mathrm{NiCrAl}$ and $\mathrm{FeCrAl}, \mathrm{Y}$ is the priority choice if only one element is used [38]. However, the amount of additions must be minimized to avoid the formation of the unwanted oxides in the scale [40,41]. A negative example is that the NiCrAlYHfSi coating has a much higher oxidation rate than the Ni+CrAlYSiHfN/AlN multilayer coating because of the formation of $\mathrm{Y}_{2} \mathrm{Hf}_{2} \mathrm{O}_{7}$ and $\mathrm{Y}(\mathrm{Si})$-related precipitates in the former coating [42], . In this work, the reactive element $Y$ together with Si within the 
$\mathrm{Ni}+\mathrm{CrAlYSi}$ cermet coating was 1 wt. $\%$, which is much less than the total content of $\mathrm{Y}$, Hf and $\mathrm{Si}(1.5 \mathrm{wt} . \%)$ in the Ni+CrAlYSiHfN coating system mentioned above [42]. The presence of $\mathrm{AlN}$ and $\mathrm{CrN}$ within the $\mathrm{Ni}+\mathrm{CrAlYSi}$ cermet coating also provides a retardation effect on the migration of $\mathrm{Y}$ and $\mathrm{Si}$ towards the coating/oxide interface. In addition, the presence of the AlN diffusion barrier also provides a positive effect on the growth of the exclusive $\alpha-\mathrm{Al}_{2} \mathrm{O}_{3}$, which will be discussed in the following part. Therefore, the $\mathrm{Ni}+\mathrm{CrAlYSiN}$ cermet coating possesses a lower oxidation rate.

After the introduction of a glass-based composite top-coat, the mass increment of the $\mathrm{Ni}+\mathrm{CrAlYSiN}$ cermet bond-coat $\left(0.09 \mathrm{mg} \mathrm{cm}^{-2}\right)$ decreased to $24 \mathrm{wt} . \%$ compared to that of the standalone $\mathrm{Ni}+\mathrm{CrAlYSiN}$ coating $\left(0.38 \mathrm{mg} \mathrm{cm}^{-2}\right)$ (Figure 4$)$. Since the inert glass-based composite top-coat incorporatingYSZ and alumina particles which did not consume oxygen during oxidation, it can be concluded that the glass-based top-coat changed the oxidation kinetics of the $\mathrm{Ni}+\mathrm{CrAlYSiN}$ bond-coat.

As stated in our previous study [18], the glass-based coating can protect the underlying alloy substrate by insulating oxygen and by changing the oxidation behavior via facilitating selective oxidation of the most reactive element within the alloy. In fact, selective oxidation of $\mathrm{Al}$ was induced in this investigation as well, and a very thin $\mathrm{Al}_{2} \mathrm{O}_{3}$ layer had developed at the top-coat/bond-coat interface within $40 \mathrm{~h}$ during oxidation at $1000{ }^{\circ} \mathrm{C}$ (Figure 7A). The factors affecting the development of $\mathrm{Al}_{2} \mathrm{O}_{3}$ scale are similar to the case in our previous study [18]. Thereafter, the oxygen partial pressure at the $\mathrm{TGO} /$ bond-coat became independent of the oxygen diffusivity through the glass-based composite top-coat. The growth of $\mathrm{Al}_{2} \mathrm{O}_{3}$ is mainly controlled by the inward diffusion of $\mathrm{O}^{2-}$ through the oxide scale, so a parabolic law was adopted to fit the oxidation kinetics of the composite coating with a Ni+CrAlYSiN cermet bond-coat (Figure4B). The corresponding parabolic rate constant was calculated to be $2.53 \times 10^{-14} \mathrm{~g}^{2} \mathrm{~cm}^{-4} \mathrm{~s}^{-1}$, which is very close to the growth rate of $\alpha-\mathrm{Al}_{2} \mathrm{O}_{3}$ above Pt-modified aluminides [43]. Based on this, it is possible to conclude that the diffusion of $\mathrm{O}^{2-}$ through the $\alpha-\mathrm{Al}_{2} \mathrm{O}_{3}$ scale rather than the glass-based top-coat is the controlling step for oxidation.

Another interesting point needs to be mentioned is that the oxidation rate of the $\mathrm{Ni}+\mathrm{CrAlYSiN}$ bond-coat with the glass-based top-coat within the initial $40 \mathrm{~h}$ was much slower than that of the standalone one (Figure 4A). This is attributed to the oxygen barrier effect of the glass-based composite top-coat. According to Chen et al.[15], the diffusion flux of molecular oxygen $\Phi$ can be expressed as: 


$$
\Phi=D \frac{C_{1}-C_{2}}{b+\xi}=C^{\prime} \frac{\mathrm{d} \xi}{\mathrm{d} t}=\frac{C^{\prime}}{\rho} \frac{\mathrm{d} m}{\mathrm{~d} t}
$$

Where $D$ is the diffusion coefficient of oxygen molecule; $C_{1}$ and $C_{2}$ are the concentrations of oxygen molecule at the interfaces of top-coat/atmosphere and bond-coat/top-coat, respectively; $b$ is the thickness of glass matrix composite top-coat; $\xi$ is the thickness of TGO developed; $\rho$ is the density of oxide of $\mathrm{Al}_{2} \mathrm{O}_{3} ; C^{\prime}$ is the concentration of oxygen ion $\left(\mathrm{O}^{2-}\right)$ at the bond-coat/top-coat interface; $\mathrm{d} m / \mathrm{d} t$ is the weight gain of unit surface per unit time, the value of which is equal to the slope of weight gain curve $\left(K_{1}\right)$ in Figure 4A. Compared with the thickness of the glass-based top-coat (about $130 \mu \mathrm{m}$ ), the thickness of TGO (about $1 \mu \mathrm{m}$ ) is negligible within the initial $40 \mathrm{~h}$. Moreover, due to the sealing effect of the glass-based composite top-coat, the oxygen partial pressure at the interface of bond-coat/top-coat was much lower than that at coating/atmosphere interface. According to Henry's law, $C_{1} / C_{2}=P_{1} / P_{2}$, where $P_{1}$ and $P_{2}$ are oxygen partial pressure at interfaces ofcoating/atmosphere and bond-coat/top-coat, respectively. Thus, $\left(C_{1}-C_{2}\right)$ can be estimated as $C_{1}$. Consequently, the oxidation rate $\mathrm{d} m / \mathrm{d} t$ can be approximated as:

$$
\frac{\mathrm{d} m}{\mathrm{~d} t}=\frac{D \rho\left(C_{1}-C_{2}\right)}{C^{\prime}(b+\xi)} \approx \frac{D \rho\left(C_{1}-C_{2}\right)}{C^{\prime} b} \approx \frac{D \rho C_{1}}{C^{\prime} b}
$$

The concentration of oxygen molecule $C_{1}$ and the concentration of oxygen ion were constant once the equilibrium was reached. From Eq. (4), the oxidation rate $(\mathrm{d} m / \mathrm{d} t)$ is determined by the diffusivity of oxygen $(D)$, and the transportation of oxygen molecule through the glass-based composite top-coat is the controlling step of oxidation. The surface dissolution of oxygen molecules in $\mathrm{SiO}_{2}$ glass $\left(C_{1}\right)$ is $5.8 \times 10^{15} \mathrm{~cm}^{3}$ at $900{ }^{\circ} \mathrm{C}$ [44]. Considering that the solubility of $\mathrm{Al}_{2} \mathrm{O}_{3}$ in liquid $\mathrm{SiO}_{2}$ at $1000{ }^{\circ} \mathrm{C}$ is $12 \mathrm{~mol} \%$ [55], the concentration of oxygen ion $\left(C^{\prime}\right)$ in glass at the top-coat/bond-coat interface, which is saturated with $\mathrm{Al}_{2} \mathrm{O}_{3}$, is obtained as $0.004 \mathrm{~mol} \mathrm{~cm}{ }^{-3}$. Based on these data, the diffusion coefficient of oxygen in glass $D_{1}$ is calculated as $7.99 \times 10^{-7} \mathrm{~cm}^{2} \mathrm{~s}^{-1}$ according to Eq. (4) for oxidation time within $40 \mathrm{~h}$. This value is very close to the diffusivity of oxygen through the devitrified glass coating prepared on the Ti-6Al-4V alloy [15]. It is two orders of magnitude higher than the reported value of oxygen diffusivity in vitreous silica $\left(D=2.7 \times 10^{-4} \exp (-113,000 / \mathrm{RT}) \mathrm{cm}^{2} \mathrm{~s}^{-1}\right)$, which results in $6.26 \times 10^{-9} \mathrm{~cm}^{2} \mathrm{~s}^{-1}$ at $1000{ }^{\circ} \mathrm{C}$ [46]. This supports that the oxygen insulation effect played an important role on the growth of alumina above the $\mathrm{Ni}+\mathrm{CrAlYSiN}$ cermet bond-coat during the initial oxidation within $40 \mathrm{~h}$. 
One may argue that the oxidation of the composite coating more than $40 \mathrm{~h}$ is still controlled by the diffusion of oxygen through the glass-based composite top-coat; and the largely decreased oxidation rate is caused by the increased viscosity of the glass matrix due to dissolution of the $\mathrm{YSZ}, \mathrm{Al}_{2} \mathrm{O}_{3}$ and other oxidation products of the $\mathrm{Ni}+\mathrm{CrAlYSiN}$ bond-coat into the glass matrix. However, as proved in our previous study [21], the glass-based top-coat became relatively stable after oxidation for $20 \mathrm{~h}$, and the oxygen diffusivity in the top-coat should become independent of oxidation time. Therefore, the reduced oxygen rate was attributed to the formation of a continuous alumina at the top-coat/bond-coat interface.

\subsection{Effect of the Ni+CrAlYSiN cermet bond-coat on cyclic oxidation resistance}

For the glass-based composite coating, cracking and peeling off (spallation) mainly occur during the cooling process. At high temperatures above the softening point, the glass matrix becomes soft, which is beneficial for stress release and micro-cracks self-healing within the glass-based coating. Besides, the adherence between the glass-based coating and the substrate is very strong, and delamination was seldom observed at the coating/substrate interface. Thus, the key factor that determines the cyclic oxidation resistance of the coating is the CTE mismatch between the bond-coat and the top-coat.

According to Tien et al [47], the biaxial stress due to thermal expansion mismatch for thin coating can be given as:

$$
\sigma_{\mathrm{rr}}=-E_{\mathrm{c}}\left(\alpha_{\mathrm{m}}-\alpha_{\mathrm{c}}\right) \frac{\Delta T}{1-v_{\mathrm{C}}}
$$

where subscript $m$ indicates the metallic substrate and $c$ refers to the coating, $E$ isYoung's modulus, $v$ is Poisson's ratio, $\Delta T$ is the difference between stress free and measurement state temperature, and $\alpha$ is thermal expansion coefficient. According to Chen et al [48], the elastic modulus and the fracture strength of the $30 \mathrm{wt} . \%$ corundum particle-reinforced glass matrix composite are 95.7 GPa and 184.5 MPa, respectively. Considering the glass transition temperature of the exclusive base glass is $\sim 600{ }^{\circ} \mathrm{C}$, above which the thermal stress can be released by viscous flow; $\Delta T$ was set as $300^{\circ} \mathrm{C}$ during cooling down of the coated specimens from $1000{ }^{\circ} \mathrm{C}$ to room temperature. As stated in our previous studies [21], adding particles of YSZ and corundum into the glass matrix improves its CTE because of the higher CTEs of YSZ $\left(11.5 \times 10^{-6}{ }^{\circ} \mathrm{C}^{-1}\right.$ for $20-1000{ }^{\circ} \mathrm{C}$ [49]) and corundum $\left(8 \times 10^{-6}{ }^{\circ} \mathrm{C}^{-1}[50]\right)$ relative to the glass matrix $\left(6.5 \times 10^{-6}{ }^{\circ} \mathrm{C}^{-1}\right.$ for $50-400{ }^{\circ} \mathrm{C}$ [47] $)$. For the 20 wt.\% YSZ and 10wt.\% alumina incorporated glass-based composite, the CTE is 
estimated to be $7.49 \times 10^{-6}{ }^{\circ} \mathrm{C}^{-1}$ for $50-500{ }^{\circ} \mathrm{C}$ [21], whilst the CTE of the $\mathrm{K} 417 \mathrm{G}$ substrate is about $17.3 \times 10^{-6}{ }^{\circ} \mathrm{C}^{-1}$ [32]. Thus, the CTE mismatch $\Delta \alpha\left(\Delta \alpha=\alpha_{m}-\alpha_{c}\right)$ is calculated to be $4.81 \times 10^{-6}{ }^{\circ} \mathrm{C}^{-1}$. Therefore, the thermal stress induced by thermal expansion mismatch is calculated to be $172.6 \mathrm{MPa}$. At this moment, the thermal stress $\sigma_{\mathrm{rr}}$ is lower than the fracture strength of the bulk glass-based composite material. This can explain why spallation of the glass-based coating was not obvious during the first 10 cycles. However, due to the microstructure degradation, which is mainly caused by interfacial reactions between YSZ and the base glassas shown in Figure 8, the CTE of the glass-based composite coating dropped to $6.04 \times 10^{-6}{ }^{\circ} \mathrm{C}^{-1}$ after thermal cycling at $1000{ }^{\circ} \mathrm{C}$ for 20 times [21]. Then, the CTE mismatch $\Delta \alpha$ after cyclic oxidation was calculated to be $6.26 \times 10^{-6}$ ${ }^{\circ} \mathrm{C}^{-1}$. Accordingly, the thermal stress was calculated to be $224.7 \mathrm{MPa}$, which was higher than the fracture strength of the bulk glass-based composite material. This might be the reason why spallation occurred after cyclic oxidation for 20 times. Even so, the actual stress generation and relaxation are more complex than this simple estimation. The growth of TGO also generated stresses, while vitreous flow of the glass matrix and creep of the TGO at high temperatures could release some stresses.

For comparison, the thermal stresses generated within the glass-based top-coat without the application of $\mathrm{Ni}+\mathrm{CrAlYSiN}$ nanocrystalline cermet bond-coat before and after cyclic oxidation were also calculated, and they were 352.1 $\mathrm{MPa}$ and 404.1 MPa, respectively. They are both much higher than the fracture strength of the bulk glass-based composite material. Therefore, it is reasonable to infer that the glass-based top-coat will spall during the initial cyclic oxidation or even cannot be directly prepared on the $\mathrm{K} 417 \mathrm{G}$ substrate just by sintering without application of the Ni+CrAlYSiN nanocrystalline cermet bond-coat. The calculated results are listed in Table V.

Furthermore, the associated plane strain caused by thermal stress $\sigma_{\text {rr }}$ can be demonstrated as $\xi_{\mathrm{rr}}=-\left(\alpha_{\mathrm{m}}-\alpha_{\mathrm{c}}\right) \Delta T$ [47], and then the stored elastic-strain energy for a unit area of the cross section of the ceramic layer with a thickness of $t_{\mathrm{c}}$ and volume of $V$ can be approximated as [51]:

$$
J_{\mathrm{rr}}=\sigma \xi V / 2 \approx E_{\mathrm{c}} t_{\mathrm{c}}\left(\alpha_{\mathrm{m}}-\alpha_{\mathrm{c}}\right)^{2} \frac{\Delta T^{2}}{1-v_{\mathrm{c}}}
$$

It can be seen that the stored elastic-strain energy in the coating is proportional to the thickness of the coating and the square of $\Delta \alpha$. For inert oxide glass-based coatings, their thickness is always much larger compared with the metallic ones in order to ensure good 
oxidation resistance. In this investigation, the glass-based composite top-coat is about $130 \mu \mathrm{m}$, which made the top-coat be very sensitive to the CTE mismatch between the top-coat and the bond-coat. With the degradation of the glass-based composite coating caused by the transformation of YSZ into zircon, the initiated cracks will propagate once the increased stored elastic-strain energy within the coating exceeds the fracture toughness.

Additionally, two measures have to be taken into account during design the coatings in order to prevent the formation of undesirable tensile stresses in the coating during cooling. First is to make sure the CTE mismatch between the oxides/glass-ceramic composite and the metal substrate is as low as possible. The second is to keep the amount of the interfacial reaction productsas low as possible. This is because the thermal expansion of these reaction products differs markedly from those of the oxides/glass-ceramic composite. Fortunately, the TGO formed above the Ni+CrAlYSiN cermet bond-coat is alumina as stated above, the CTE of which is just between that of the glass-based composite top-coat and the $\mathrm{Ni}+\mathrm{CrAlYSiN}$ cermet bond-coat.

\subsection{Effect of interfacial reactions on the development of TGO development in the cermet bond-coat}

The interfacial reactions in this investigation can be categorized into three types according to the place where they occurred: a) interfacial reactions within the top-coat between the added oxides and the glass matrix; b) interfacial reactions at the top-coat/TGO interface between the glass matrix and TGO; c) interfacial reactions at the bond-coat/substrate interface between the bond-coat and the substrate. Each of them played an important role in the TGO development of the nanocrystalline $\mathrm{Ni}+\mathrm{CrAlYSiN}$ cermet bond-coat.

\section{a) Interfacial reactions within the top-coat}

The mainly interfacial reactions within the top-coat were the interactions between the oxides $\left(\mathrm{Al}_{2} \mathrm{O}_{3}\right.$ and YSZ) and the glass matrix. For silicate glass, their oxygen diffusivity is closely related to its microstructure. Generally, the higher the viscosity of the silicate glass matrix, the lower the oxygen diffusivity within the glass matrix. However, in this investigation, the glass-based top-coat was not stable; it evolved with the proceeding of the interactions between the glass matrix and the additions of corundum and YSZ.

Because the mol ratio of $\mathrm{Al}_{2} \mathrm{O}_{3} / \mathrm{M}_{\mathrm{x}} \mathrm{O}(\mathrm{M}=\mathrm{Ca}, \mathrm{Na}, \mathrm{K}, \mathrm{Zn})$ in this glass is much lower than $1(0.21)$ [21], the added intermediate $\mathrm{Al}_{2} \mathrm{O}_{3}$ particles dissolved into the base glass 
mainly as a glass network former in the form of $\mathrm{AlO}_{4}$ tetrahedron. The charge deficiency of $\mathrm{Al}^{3+}$ is compensated by the cations of $\mathrm{Ca}^{2+}, \mathrm{Na}^{+}$, and $\mathrm{K}^{+}$in the base glass. Consequently, the degree of polymerization of the structure of the glass was improved due to the increased number of bridging oxygen (BO) that bridges two $\mathrm{SiO}_{4}$ or $\mathrm{AlO}_{4}$ tetrahedra. Thus, the viscosity of the base glass is remarkably increased, whilst the mobility of $\mathrm{O}^{2-}$ is largely reduced. Additionally, the incorporated alumina reacted with the glass matrix, and the reaction product was identified as $\mathrm{ZnAl}_{2} \mathrm{O}_{4}$. Because $\mathrm{ZnO}$ was added into the glass as flux agent and is usually classified as intermediate in the glass structure [52], the extraction of $\mathrm{Zn}^{2+}$ ions by this reaction is believed to increase the viscosity of the residual glass.

Similarly with $\mathrm{Al}_{2} \mathrm{O}_{3}$, the dissolution of YSZ can increase the viscosity of the base glass as well. The dissolution of $\mathrm{Zr}^{4+}$ into the base glass occupying the octahedral coordination, with the $\mathrm{ZrO}_{6}$ octahedra being corner-linked to $\mathrm{SiO}_{4}$ tetrahedra, is beneficial for increasing the viscosity of the glass-based composite top-coat. It has been proved in our previous study that the dissolution of YSZ can retard the precipitation of $\mathrm{t}-\mathrm{ZrO}_{2}$ or $\mathrm{CaZrTi}_{2} \mathrm{O}_{7}$ by reducing the diffusivity of $\mathrm{Zr}^{4+}$ [25]. Nevertheless, as a nucleating agent in the silicate glass, YSZ contributed much less to the viscosity of the base glass due to its limited solubility within the glass matrix compared with $\mathrm{Al}_{2} \mathrm{O}_{3}$ [21] Unlike $\mathrm{Al}_{2} \mathrm{O}_{3}$, YSZ transformed into zircon via reacting with the glass matrix, consuming large amount of glass network formers $\mathrm{Si}^{4+}$ ions. This gave rise to the enrichment of glass network modifiers $\left(\mathrm{Ca}^{2+}, \mathrm{Na}^{+}, \mathrm{K}^{+}\right)$in the residual glass, which will destroy the integrity of the glass network and then lower the viscosity of the glass matrix. Although these enriched alkaline or alkaline-earth ions can facilitate the dissolution of $\mathrm{Al}_{2} \mathrm{O}_{3}$ and $\mathrm{YSZ}$, considering that the $Z / a^{2}$ value of $\mathrm{Si}^{4+}(Z$ represents valence while $a$ represents the distance between oxygen ion and the positive ion) is larger than that of either $\mathrm{Al}^{3+}$ and $\mathrm{Zr}^{4+}$, the reaction will decrease the viscosity of the glass matrix at last.

Apparently, the dissolution of $\mathrm{Al}_{2} \mathrm{O}_{3}$ and YSZ prevailed in this investigation, and the viscosity of the glass matrix was greatly improved with the dissolution of $\mathrm{Al}_{2} \mathrm{O}_{3}$ and YSZ. This can be supported by the existence of $\alpha-\mathrm{Al}_{2} \mathrm{O}_{3}$ above the Ni+CrAlYSiN bond-coat (Figure 7 and Figure 8C) and the precipitation of albite from the glass matrix (Figure 5). Accordingly, the selective oxidation of Al within the bond-coat was enhanced due to the extremely low oxygen partial pressure at the top-coat/bond-coat interface.

\section{b) Interfacial reactions at the top-coat/TGO interface}

As stated above, the active glass can attack the developed TGO at high temperatures, 
leading to the dissolution of the oxides such as $\mathrm{NiO}$ and $\mathrm{Al}_{2} \mathrm{O}_{3}$ into the glass matrix. This leads to a much higher oxidation rate of the bond-coat because of the durative consumption of the most reactive element. Fortunately, the attack of the active glass to the TGO in this investigation was limited. Otherwise, the alumina forming at the bond-coat/top-coat would dissolve into the glass matrix, and the oxidation rate of bond-coat would be much higher. This is probably caused by the dissolution of the added corundum particles, which raise the content of $\mathrm{Al}_{2} \mathrm{O}_{3}$ in the base glass to a value very close to the solubility. However, $\mathrm{NiO}$ or $\mathrm{NiAl}_{2} \mathrm{O}_{4}$ might form during the initial oxidation process. Because they are under-saturated in the glass matrix, their absence at the $\mathrm{TGO} /$ top-coat interface in this investigation is probably caused by their dissolution into the glass matrix if there is any (Figure 7).

\section{c) Interfacial reactions at the bond-coat/substrate interface}

The interfacial reactions at the bond-coat/substrate interface were caused by interdiffusion between the Ni+CrAlYSiN cermet bond-coat and the K417G substrate. Without the AlN diffusion barrier, granular and needle-like AlN formed at the surface of the K417G substrate (Figure 11), which reduces the outward diffusion flux of Al towards the oxidation front. Furthermore, $\mathrm{Cr}$ within the bond-coat or as the reaction product of the reaction between $\mathrm{CrN}$ and $\mathrm{Al}$ diffused into the substrate during oxidation. The above reasons would lead to an unstable $\mathrm{TGO} /$ bond-coat interface and shorten service life of the cermet bond-coat. This is why the AlN diffusion barrier was prepared between the substrate and the cermet bond-coat.

Additionally, it is noteworthy that the application of the AlN diffusion barrier affects the microstructure of oxide scale. As evidenced by Zhu et al [30,32], the external oxide scales of the Ni+CrAlYSiN coating with and without the AlN diffusion barrier were just $\alpha-\mathrm{Al}_{2} \mathrm{O}_{3}$ and a bi-layered oxide comprised of out-layer $\mathrm{NiCr}_{2} \mathrm{O}_{4}$ and inner-layer $\alpha-\mathrm{Al}_{2} \mathrm{O}_{3}$ after oxidation at $1000{ }^{\circ} \mathrm{C}$ for $100 \mathrm{~h}$, respectively.

The chemical degradation of metallic coatings under isothermal oxidation conditions is mainly caused by oxidation at the coating/atmosphere interface and interdiffusion at the coating/substrate interface. In this investigation, the growth rate of $\alpha-\mathrm{Al}_{2} \mathrm{O}_{3}$ above the bond-coat was extremely slow due to oxygen insulation effect arising from the glass-based top-coat (Figure 4). Moreover, with the application of the AlN diffusion barrier, the consumption of Al by interdiffusion was inhibited. Hence, the service life of the cermet bond-coat is greatly extended. 


\section{Conclusions}

A ceramic particle reinforced glass matrix composite coating with a novel $\mathrm{Ni}+\mathrm{CrAlYSiN}$ cermet bond-coat and an AlN diffusion barrier was prepared on $\mathrm{K} 417 \mathrm{G}$ superalloy, and its oxidation behavior at $1000{ }^{\circ} \mathrm{C}$ was investigated, and the following conclusions can be drawn:

(1) Selective oxidation of $\mathrm{Al}$ within the $\mathrm{Ni}+\mathrm{CrAlYSiN}$ bond-coat was enhanced by the glass-based composite top-coat due to the oxygen insulation effect. The growth of the continuous $\alpha-\mathrm{Al}_{2} \mathrm{O}_{3}$ scale developed above the bond-coat was controlled by the diffusion of oxygen molecules through the glass-based composite top-coat and the diffusion of $\mathrm{O}^{2-}$ ions through the $\alpha-\mathrm{Al}_{2} \mathrm{O}_{3}$ scale for the oxidation time before and after $40 \mathrm{~h}$. The parabolic oxidation rate constant of the Ni+CrAlYSiN bond-coat was one order of magnitude lower than the standalone $\mathrm{Ni}+\mathrm{CrAlYSiN}$ coating.

(2) The cyclic oxidation resistance of the $\mathrm{SiO}_{2}-\mathrm{Al}_{2} \mathrm{O}_{3}-\mathrm{ZrO}_{2}-\mathrm{TiO}_{2}$-based glass coating on $\mathrm{K} 417 \mathrm{G}$ Ni-based superalloy at $1000{ }^{\circ} \mathrm{C}$ was improved after the introducing of a novel $\mathrm{Ni}+\mathrm{CrAlYSiN}$ bond-coat, which reduced mismatch of thermal expansion.

(3) Cyclic oxidation resistance of the glass-based composite coating degraded as YSZ transformed into zircon; and the transformation was caused by interfacial reactions between YSZ and the glass matrix.

(4) The inter-diffusion between the Ni+CrAlYSiN cermet bond-coat and the K417G superalloy at $1000{ }^{\circ} \mathrm{C}$ was inhibited through the introducing of a AlN diffusion barrier

\section{Acknowledgements}

This work is sponsored by National Natural Science Foundation of China (51501155, 51501109, 51603169), National Key R\&D Program of China (2017YFB0306100), Natural Science Foundation of Shaanxi Province, China (2016JM5045, 2017JQ5050), and Innovative Talent Promotion Program of Shaanxi Province, China Scientific and Technological Innovation Team under Grant 2017KCT-06. 


\section{References}

[1] G.W. Goward, Progress in coatings for gas turbine airfoils, Surf. Coat. Technol. 109 (1998) 73-79.

[2] M.J. Pomeroy, Coatings for gas turbine materials and long term stability issues, Mater. Des. 26 (2005) 223-231.

[3] R. Sivakumar, B.L. Mordike, High temperature coatings for gas turbine blades: a review, Surf. Coat. Technol. 37 (1989) 136-160.

[4] D.A. Berztiss, R.R. Cerchiara, E.A. Gulbransen, F.S. Pettit and G. H. Meier, Oxidation of $\mathrm{MoSi}_{2}$ and comparison with other silicide materials, Mater. Sci. Eng. A 155 (1992) 165-181.

[5] C. Yu, S. Zhu, D. Wei and F. Wang, Amorphous sol-gel $\mathrm{SiO}_{2}$ film for protection of Ti6Al4V alloy against high temperature oxidation, Surf. Coat. Technol. 201 (2006) 5967-5972.

[6] S. Zhu, F. Wang, H. Lou and W. Wu, Reactive sputter-deposition of alumina films on superalloys and their high-temperature corrosion-resistance, Surf. Coat. Technol. 71 (1995) 9-15.

[7] Z. Tang, F. Wang and W. Wu, Effect of $\mathrm{Al}_{2} \mathrm{O}_{3}$ and enamel coatings on $900{ }^{\circ} \mathrm{C}$ oxidation and hot corrosion behaviors of gamma-TiAl, Mater. Sci. Eng. A 276 (2000) 70-75.

[8] S. Das, S. Datta, D. Basu and G. C. Das, Hot corrosion of glass coating on nickel base superalloy, Ceram. Int. 34 (2008) 1215-1222.

[9] I.W. Donald, P.M. Mallinson, B.L. Metcalfe, L.A. Gerrard and J.A. Fernie, Recent developments in the preparation, characterization and applications of glass- and glass-ceramic-to metal seals and coatings, J. Mater. Sci. 46 (2011) 1975-2000.

[10] F. Tang, G. Chen, R.K. Brow, J.S. Volz, M.L. Koenigstein, Corrosion resistance and mechanism of steel rebar coated with three types of enamel, Corros. Sci. 59 (2012) 157-168.

[11] M. Chen, W. Li, M. Shen, S. Zhu, F. Wang, Glass coatings on stainless steels for high-temperature oxidation protection: Mechanisms, Corros. Sci. 82 (2014) 316-327.

[12] W. Li, S. Zhu, C. Wang, M. Chen, M. Shen, F. Wang, $\mathrm{SiO}_{2}-\mathrm{Al}_{2} \mathrm{O}_{3}$-glass composite coating on Ti-6Al-4V alloy: oxidation and interfacial reaction behavior, Corros. Sci. 74 (2013) 367-378.

[13] S. Sarkar, S. Datta, S. Das and D. Basu, Oxidation protection of gamma-titanium aluminide using glass-ceramic coatings, Surf. Coat. Technol. 203 (2009) 1797-1805.

[14] S. Das, S. Datta, D. Basu, and G. C. Das, Glass-ceramics as oxidation resistant bond coat in thermal barrier coating system, Ceram. Int. 35 (2009) 1403-06.

[15] M. Chen, W. Li, M. Shen, S. Zhu, F. Wang, Glass-ceramic coatings on titanium alloys for high temperature oxidation protection: Oxidation kinetics and microstructure, Corros. Sci. 74 (2013) 178-186.

[16] M. Dietrich, V. Verlotski, R. Vaßen and D. Stöver, Metal-glass based composites for novel TBC-systems, Mat. -wiss. U. Werkstofftech 32 (2001) 669-72.

[17] X. Wang, S. Zhu, Y. Zhang, M. Chen, F. Wang, Interfacial microstructure evolution of 
glass - based coating on IC10 superalloy with a $\mathrm{Ni}_{3} \mathrm{Al}$ bond- coat at $1050^{\circ} \mathrm{C}, \mathrm{J}$. Am. Ceram. Soc. 100(8) (2017) 3451-3466.

[18] X. Wang, S. Zhu, Z. Gua, M. Chen, F. Wang, Effect of YSZ-incorporated glass-based composite coating on oxidation behavior of $K 438 G$ superalloy at $100{ }^{\circ} \mathrm{C}$, J. Eur. Ceram. Soc. 37 (2017) 1013-1022.

[19] A.M. Espino, L.A. Díaz, A. Fernández, R. Torrecillas, $\mathrm{Al}_{2} \mathrm{O}_{3}-\mathrm{ZrO}_{2}-\mathrm{SiO}_{2}$ ternary glasses for molybdenum oxidation barriers, J. Am. Ceram. Soc. 88(4) (2005) 1000-1003.

[20] C. Isola, P. Appendino, F. Bosco, M. Ferraris, and M. Salvo, Protective glass coating for carbon-carbon composites, Carbon 36(7-8) (1998) 1213-1218.

[21] X. Wang, M. Shen, M. Chen, S. Zhu, F. Wang, Microstructure stabilization of a novel glass/YSZ composite coating material by adding alumina particles, Ceram. Int. 41 (2015) 9753-9762.

[22] X. Wang, M. Chen, S. Zhu, F. Wang, Oxidation behavior of glass-based composite thermal barrier coating on $\mathrm{K} 417 \mathrm{G}$ superalloy with a NiCoCrAlY bond coat at $1000{ }^{\circ} \mathrm{C}$, Surf. Coat. Technol. 270 (2015) 314-323.

[23] M. Chen, M. Shen, S. Zhu, F. Wang, Y. Niu, Preparation and thermal shock behavior at $1000{ }^{\circ} \mathrm{C}$ of a glass-alumina-NiCrAlY tri-composite coating on $\mathrm{K} 38 \mathrm{G}$ superalloy, Surf. Coat. Technol. 206 (2012) 2566-2571.

[24] M. Chen, M. Shen, X. Wang, S. Zhu and F. Wang, Oxidation and thermal shock behavior of a glass-alumina composite coating on K38G superalloy at $1000^{\circ} \mathrm{C}$, J. Mater. Sci. Technol. 28(5) (2012) 433-438.

[25] X. Wang, M. Chen, S. Zhu and F. Wang, Phase evolution of $\mathrm{SiO}_{2}-\mathrm{Al}_{2} \mathrm{O}_{3}-\mathrm{ZnO}-\mathrm{CaO}-\mathrm{ZrO}_{2}-\mathrm{TiO}_{2}$-based glass with added YSZ particles, J. Am. Ceram. Soc. 96(5) (2013) 1456-1463.

[26] X. Wang, M. Chen, S. Zhu, F. Wang, Interfacial reactions between a $\mathrm{SiO}_{2}-\mathrm{Al}_{2} \mathrm{O}_{3}-\mathrm{ZnO}-\mathrm{CaO}$ based glass and alpha alumina, Surf. Coat. Technol. 232 (2013) 6-12.

[27] J. A. Haynes, B. A. Pint, W. D. Porter and I. G. Wright, Comparison of thermal expansion and oxidation behavior of various high-temperature coating materials and superalloys, Mater. High Temp. 21(2) (2004) 87-94.

[28] T.A. Taylor, P.N. Walsh, Thermal expansion of MCrAlY alloys, Surf. Coat. Technol. 177 (2004) 24-31.

[29] I. W. Donald, Preparation, properties and chemistry of glass and glass-ceramic-to-metal seals and coatings, J. Mater. Sci. 28 (1993) 2841-2886.

[30] L. Zhu, S. Zhu, F. Wang, Preparation and oxidation behavior of nanocrystalline $\mathrm{Ni}+\mathrm{Cr}$ AlYSiN composite coating with AlN diffusion barrier on Ni-based superalloy K417, Corros. Sci. 60 (2012) 265-274.

[31] T. G. Kollic, Measurement of the thermal-expansion coef5cient of nickel from 300 to $1000 \mathrm{~K}$ 
and determination of the power-law constants near the Curie temperatures, Phys. Rev. B 16(11) (1977) 4872-4881.

[32] L. Zhu, S. Zhu, F. Wang, J. Zhang, Comparison of the cyclic oxidation behavior of a low expansion Ni+CrAlYSiN nanocomposite and a NiCrAlYSi coating, Corros. Sci. 80 (2014) 393-401.

[33] P. Ren, S. Zhu, F. Wang, TEM study of the evolution of sputtered Ni+CrAlYSiHfN nanocomposite coating with an AlN diffusion barrier at high temperature, Surf. Coat. Technol. 286 (2016) 262-267.

[34] P. Ren, S.L. Zhu, F.H. Wang, Characterization and oxidation behavior of sputtered nanocomposite Ni+CrAlYSiHfN coating, Corrosion 71 (2015) 523-535.

[35] D.J. Young, High temperature oxidation and corrosion of metals, Elsevier, Amsterdam, 2008.

[36] Y. Niu, S. Wang, F. Gao, Z.G. Zhang, F. Gesmundo, The nature of the third-element effect in the oxidation of Fe-xCr-3at.\% Al alloys in 1 atm $\mathrm{O}_{2}$ at $1000{ }^{\circ} \mathrm{C}$, Corros. Sci. 50 (2008) 345-356.

[37] Y. Niu, X.J. Zhang, Y. Wu a, F. Gesmundo, The third-element effect in the oxidation of

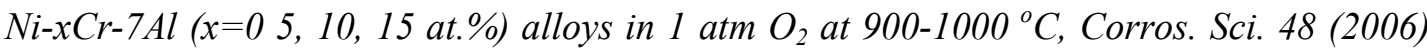
4020-4036.

[38] P. Ren, S. Zhu, F. Wang, Microstructure and oxidation behavior of a Ni+CrAlYSiHfN/AlN multilayer coating fabricated by reactive magnetron sputtering, Corros. Sci. 104 (2016) 197-206.

[39] B.A. Pint, Progress in understanding the reactive element effect since the Whittle and Stringer literature review, in: P.F. Tortorelli, I.G. Wright, P.Y. Hou(Eds.), John Stringer Symposium on High Temperature Corrosion, ASM International, Materials Park, Novelty, 2003, pp. 9-19.

[40] P.Y. Hou, The reactive element effect-past, present and future, Mater. Sci. Forum 696 (2011) $39-44$.

[41] W. Wang, P. Yu, F.H. Wang, S.L. Zhu, The effect of yttrium addition on the isothermal oxidation behavior of sputtered K38 nanocrystalline coating at $1273 \mathrm{~K}$ in air, Surf. Coat. Technol. 201 (2007) 7425-7431.

[42] H. Guo, T. Zhang, S. Wang, S. Gong, Effect of Dy on oxide scale adhesion of NiAl coatings at $1200^{\circ} \mathrm{C}$, Corros. Sci. 53 (2011) 2228-2232.

[43] D.K. Das, Microstructure and high temperature oxidation behavior of Pt-modified aluminide bond coats on Ni-base superalloys, Prog. Mater. Sci. 58 (2013) 151-182.

[44] K. Kajihara, T. Miura, H. Kamioka, M. Kirano, L. Skuja, H. Hosono, Surface dissolution and diffusion of oxygen molecules in $\mathrm{SiO}_{2}$ glass, J. Ceram. Soc. Jpn. 112 (2004) 559-562.

[45] S.H. Risbud, J.A. Pask, $\mathrm{SiO}_{2}-\mathrm{Al}_{2} \mathrm{O}_{3}$ metastable phase equilibrium diagram without mullite, J. Mater. Sci. 13 (1978) 2449-2454. 
[46] M.A. Lamkin, F.L. Riley, Oxygen mobility in silicon glasses: a review, J. Eur. Ceram. Soc. 10 (1992) 347-367

[47] J.K. Tien and J.M., Davidson, Oxide spallation mechanisms. In Stress effects and the oxidation of metals, ed. J.V. Cathcart, New York, AIME, 1975, p.200.

[48] M. Chen, S. Zhu, M. Shen, F. Wang, and Y. Niu, Thermophysical properties of alumina particle reinforced glass matrix composites, Int. J. Appl. Ceram. Technol., 10(2) (2013) 224-233.

[49] X.Q. Cao, R. Vassen, D. Stoeverb, Ceramic materials for thermal barrier coatings, J. Eur. Ceram. Soc. 24 (2004) 1-10.

[50] W.Z. Zhu, S.C. Deevi, Development of interconnect materials for solid oxide fuel cells, Mater. Sci. Eng. A 348 (2003) 227-243.

[51] Thornton, J., D. Cookson, and E. Pescott, The measurement of strains within the bulk of aged and as-sprayed thermal barrier coatings using synchrotron radiation, Surf. Coat. Technol. 120 (1999) 96-102.

[52] D.R. Askeland, P.P. Phule, Inorganic Glasses, Essentials of Materials Science and Engineering, Cengage Learning, Singapore, 2004, p. 460-465.

Table 1 Composition of the glass frit (wt. \%)

\begin{tabular}{ccccccccc}
\hline $\mathrm{SiO}_{2}$ & $\mathrm{Al}_{2} \mathrm{O}_{3}$ & $\mathrm{ZnO}$ & $\mathrm{CaO}$ & $\mathrm{ZrO}_{2}$ & $\mathrm{TiO}_{2}$ & $\mathrm{~B}_{2} \mathrm{O}_{3}$ & $\mathrm{Na}_{2} \mathrm{O}$ & $\mathrm{KNO}_{3}$ \\
\hline 58.26 & 5.98 & 9 & 3.66 & 5.29 & 2.75 & 4.66 & 3.4 & 7 \\
\hline
\end{tabular}

Table II Chemical composition of K417G superalloy (wt.\%)

\begin{tabular}{cccccccccc}
\hline $\mathrm{C}$ & $\mathrm{Cr}$ & $\mathrm{Co}$ & $\mathrm{Mo}$ & $\mathrm{Al}$ & $\mathrm{Ti}$ & $\mathrm{V}$ & $\mathrm{B}$ & $\mathrm{Zr}$ & $\mathrm{Ni}$ \\
\hline 0.17 & 9.0 & 10.0 & 3.0 & 5.25 & 4.4 & 0.75 & 0.018 & 0.07 & Balance \\
\hline
\end{tabular}


Table III Typical deposition parameters for the Ni+CrAlYSiN cermet coating and the AlN diffusion barrier

\begin{tabular}{cccccc}
\hline & $\begin{array}{c}\text { Arc } \\
\text { voltage } \\
(\mathrm{V})\end{array}$ & $\begin{array}{c}\text { Arc } \\
\text { current }\end{array}$ & $\begin{array}{c}\text { Bias } \\
\text { voltage } \\
(\mathrm{A})\end{array}$ & $\begin{array}{c}\text { Bias } \\
\text { duty } \\
(\mathrm{V})\end{array}$ & $\begin{array}{c}\text { Temperature } \\
(\%)\end{array}$ \\
\hline Bombardment cleaning & 30 & 60 & -900 & 15 & $195-215$ \\
\hline AlNdiffsusion barrier & 30 & 70 & -500 & 20 & $195-215$ \\
\hline $\begin{array}{c}\text { Ni+CrAlYSiN } \\
\text { cermet coating }\end{array}$ & 19 & 70 & -300 & 20 & $195-215$ \\
\hline
\end{tabular}

Table IV Typical preparation parameters of the ceramic particle reinforced glass-based composite top-coat

\begin{tabular}{|c|c|c|c|c|c|}
\hline & \multirow{2}{*}{ Layer } & \multicolumn{3}{|c|}{ Formula (wt.\%) } & \multirow{2}{*}{ Sintering } \\
\hline & & Corundum & YSZ & Glass & \\
\hline \multirow{8}{*}{ Top-coat } & \multirow{5}{*}{ under-layer } & \multirow{5}{*}{17} & \multirow{5}{*}{5} & \multirow{5}{*}{78} & $\begin{array}{c}\text { Soaking at } 400^{\circ} \mathrm{C} \text { for } 2 \\
h\end{array}$ \\
\hline & & & & & $400-800^{\circ} \mathrm{C}, 20 / \mathrm{min}$ \\
\hline & & & & & $800-1050^{\circ} \mathrm{C}, 10 / \mathrm{min}$ \\
\hline & & & & & $1050^{\circ} \mathrm{C}$ for $15 \mathrm{~min}$; cool \\
\hline & & & & & in air \\
\hline & \multirow{3}{*}{ upper-layer } & \multirow{3}{*}{10} & \multirow{3}{*}{25} & \multirow{3}{*}{65} & $\begin{array}{c}\text { Soaking at } 400{ }^{\circ} \mathrm{C} \text { for } 2 \\
h\end{array}$ \\
\hline & & & & & $400-1050^{\circ} \mathrm{C}, 20 / \mathrm{min}$ \\
\hline & & & & & $\begin{array}{c}1050^{\circ} \mathrm{C} \text { for } 15 \mathrm{~min} \text {; cool } \\
\text { in air }\end{array}$ \\
\hline
\end{tabular}


Table V Measured thermo physical properties of the glass-based composite coating and calculated thermal stress within the coating caused by CTE mismatch

\begin{tabular}{|c|c|c|c|c|c|}
\hline Parameter & $\begin{array}{c}\boldsymbol{E}_{\mathbf{c}} \\
(\mathrm{GPa})\end{array}$ & $\begin{array}{l}\Delta T \\
\left({ }^{\circ} \mathrm{C}\right)\end{array}$ & $\begin{array}{c}\sigma \\
(\mathrm{MPa})\end{array}$ & $\begin{array}{c}\boldsymbol{\alpha}_{\mathbf{m}} \\
\left(\times 10^{-60} \mathrm{C}^{-1}\right)\end{array}$ & $\begin{array}{c}\boldsymbol{\alpha}_{\mathrm{BC}} \\
\left(\times 10^{-60} \mathrm{C}^{-1}\right)\end{array}$ \\
\hline Value & $\sim 95.7[35]$ & $\sim 300$ & $\sim 184.5[35]$ & $17.3[32]$ & $\sim 12.3[30]$ \\
\hline State & \multicolumn{3}{|c|}{ As-prepared } & \multicolumn{2}{|c|}{ After cyclic oxidation } \\
\hline $\boldsymbol{\alpha}_{\mathbf{c}}\left(\times 10^{-60} \mathrm{C}^{-1}\right)$ & \multicolumn{2}{|c|}{$\sim 7.49 \times 10^{-6}[21]$} & & \multicolumn{2}{|c|}{$\sim 6.04[21]$} \\
\hline Structure & Without $B C$ & With $B C$ & & Without BC & With $B C$ \\
\hline$\Delta \boldsymbol{\alpha}\left(\times 10^{-60} \mathrm{C}^{-1}\right)$ & 9.81 & 4.81 & & 11.26 & 6.26 \\
\hline $\boldsymbol{\sigma}_{\mathbf{r r}}^{*}(\mathrm{MPa})$ & -352.1 & -172.6 & & -404.1 & -224.7 \\
\hline
\end{tabular}

"The Poisson's ratio of the glass matrix was assumed as 0.2 . 
Figures

Figure $1 \mathrm{X}$-ray diffraction pattern of the as-prepared composite coating

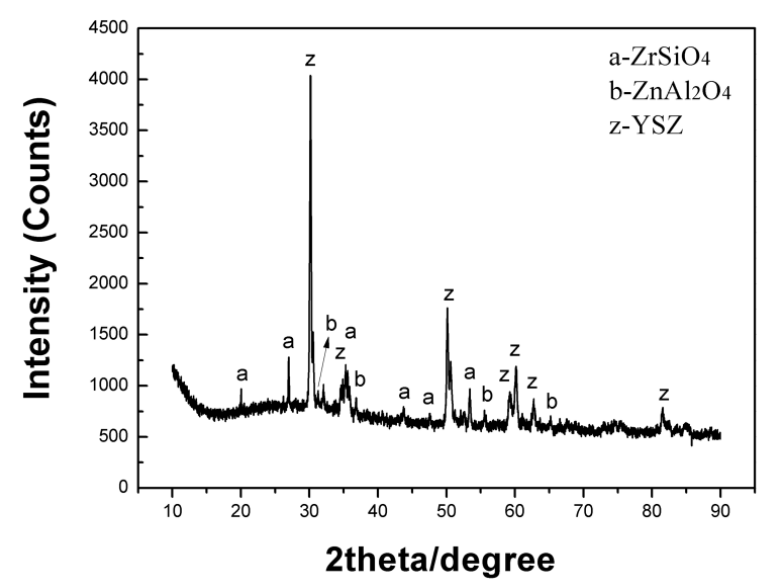


Figure 2 Optical image (A), Surface morphology (B) and cross-sectional BSE microstructure $(\mathrm{C})$ of the as-prepared composite coating.
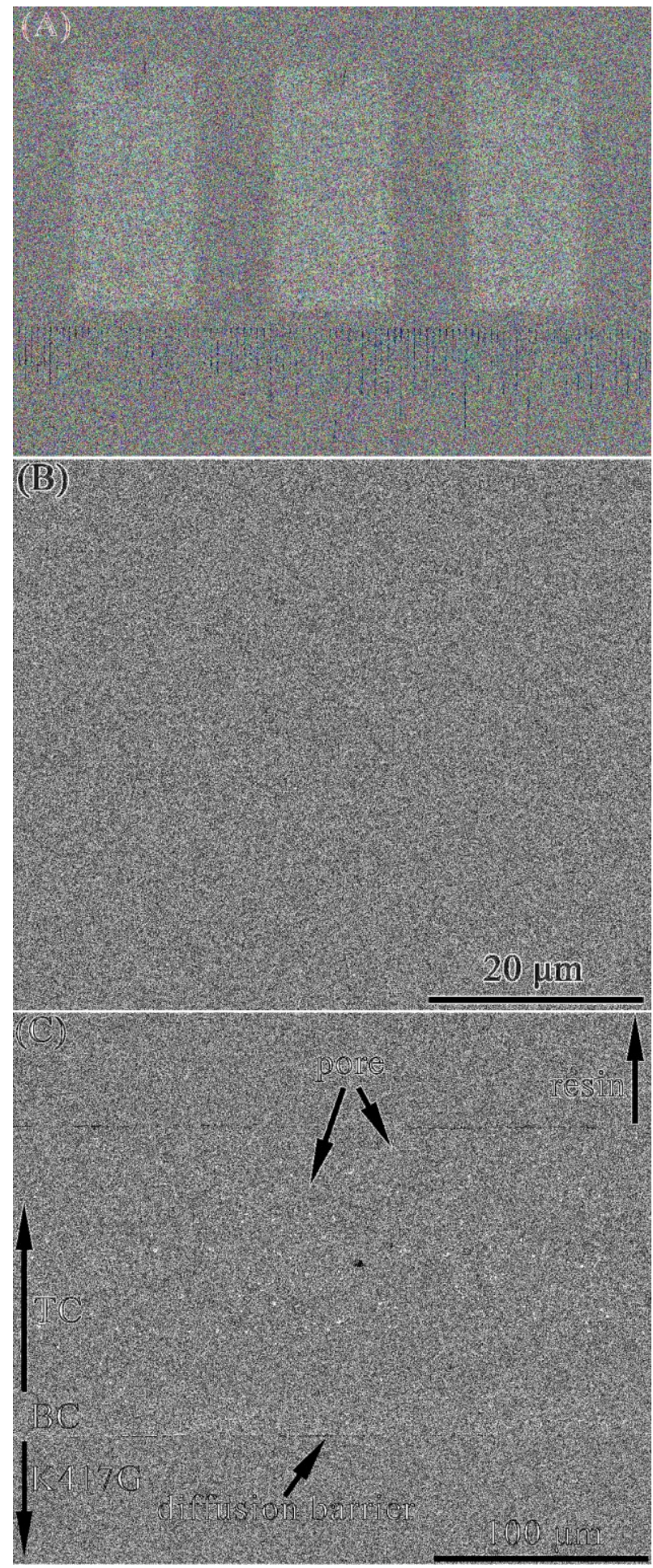
Figure 3 Cross-sectional BSE image and the corresponding element distribution maps of the as-prepared composite coating.

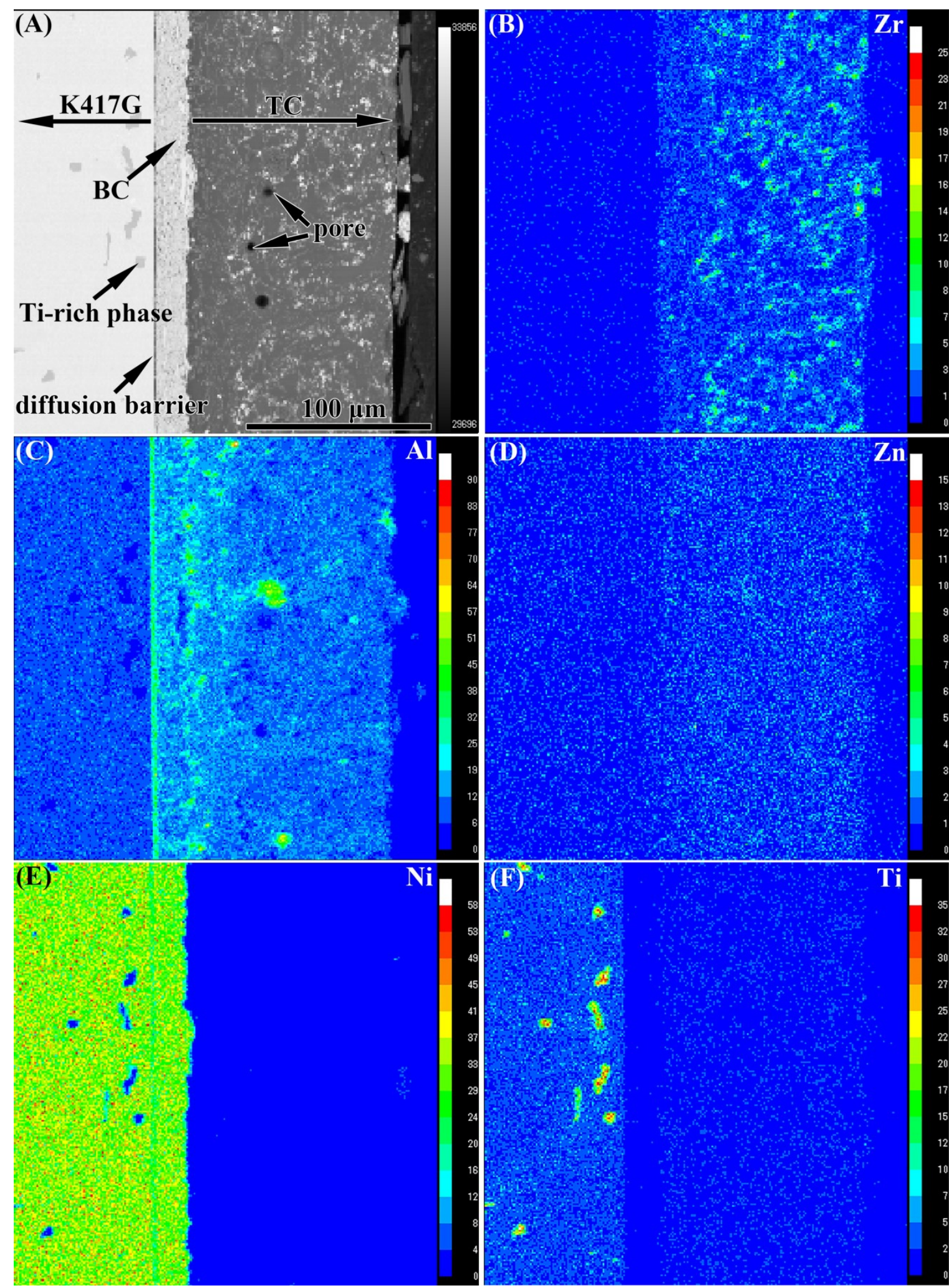


Figure 4 Isothermal oxidation kinetics of the $\mathrm{Ni}+\mathrm{CrAlYSiN}$ bond-coat with and without the glass-based composite top-coat at $1000^{\circ} \mathrm{C}$ in static air. The scatter bars show the deviation of maximum/minimum values from the means.
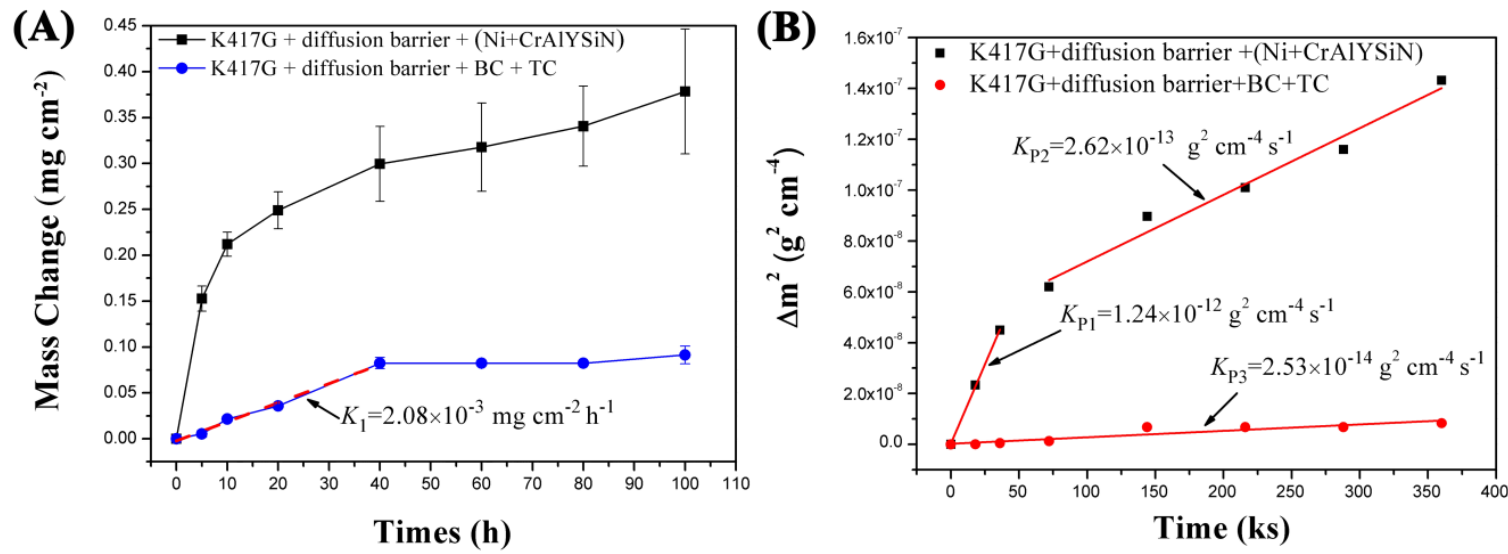

Figure $5 \mathrm{X}$-ray diffraction pattern of the composite coating after oxidation at $1000{ }^{\circ} \mathrm{C}$ for $100 \mathrm{~h}$.

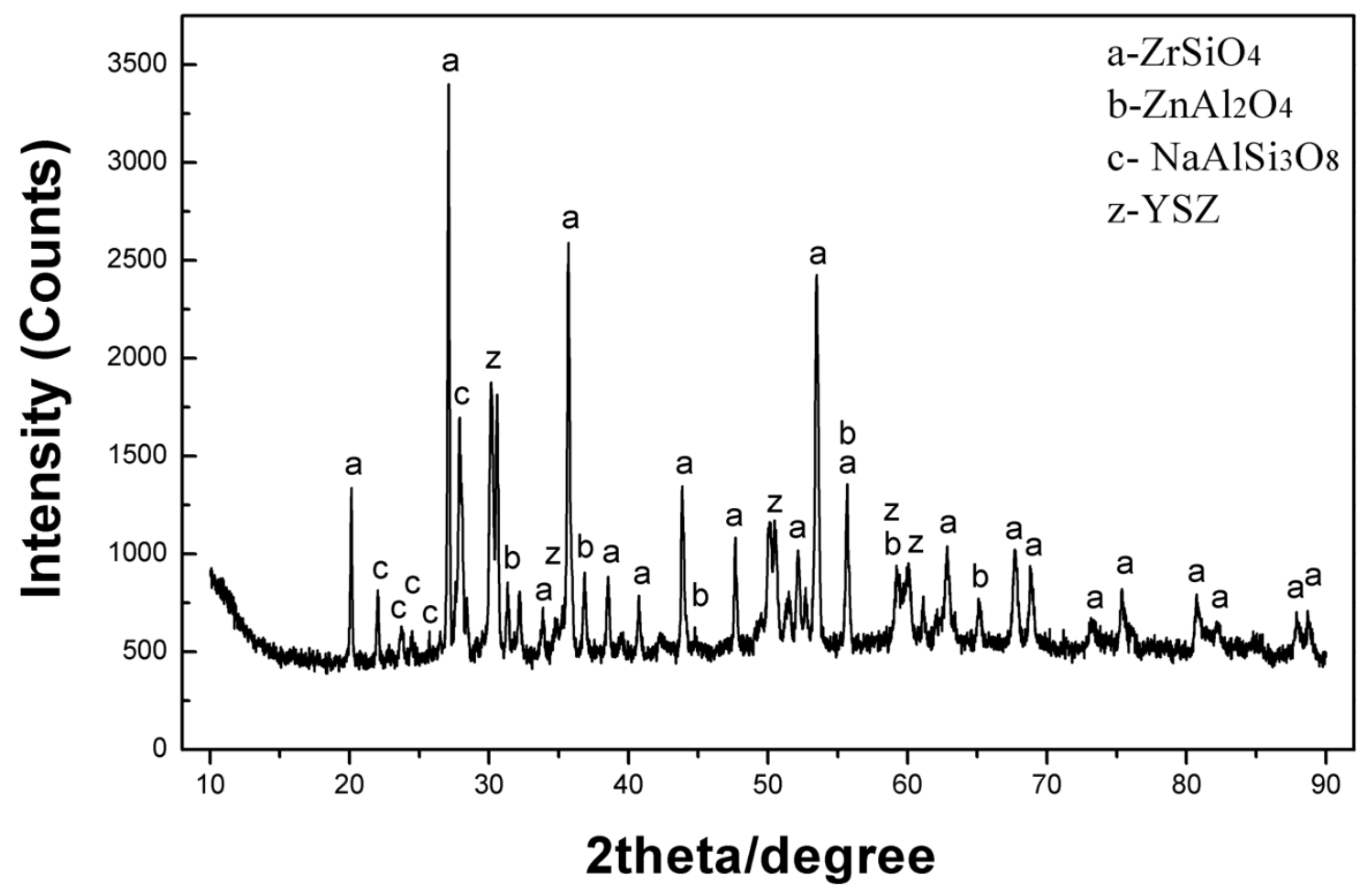


Figure 6 Surface morphology (A), cross-sectional BSE image (B) and microstructure near the bond-coat $(\mathrm{C})$ of the composite coating after isothermal oxidation at $1000{ }^{\circ} \mathrm{C}$ for $100 \mathrm{~h}$.

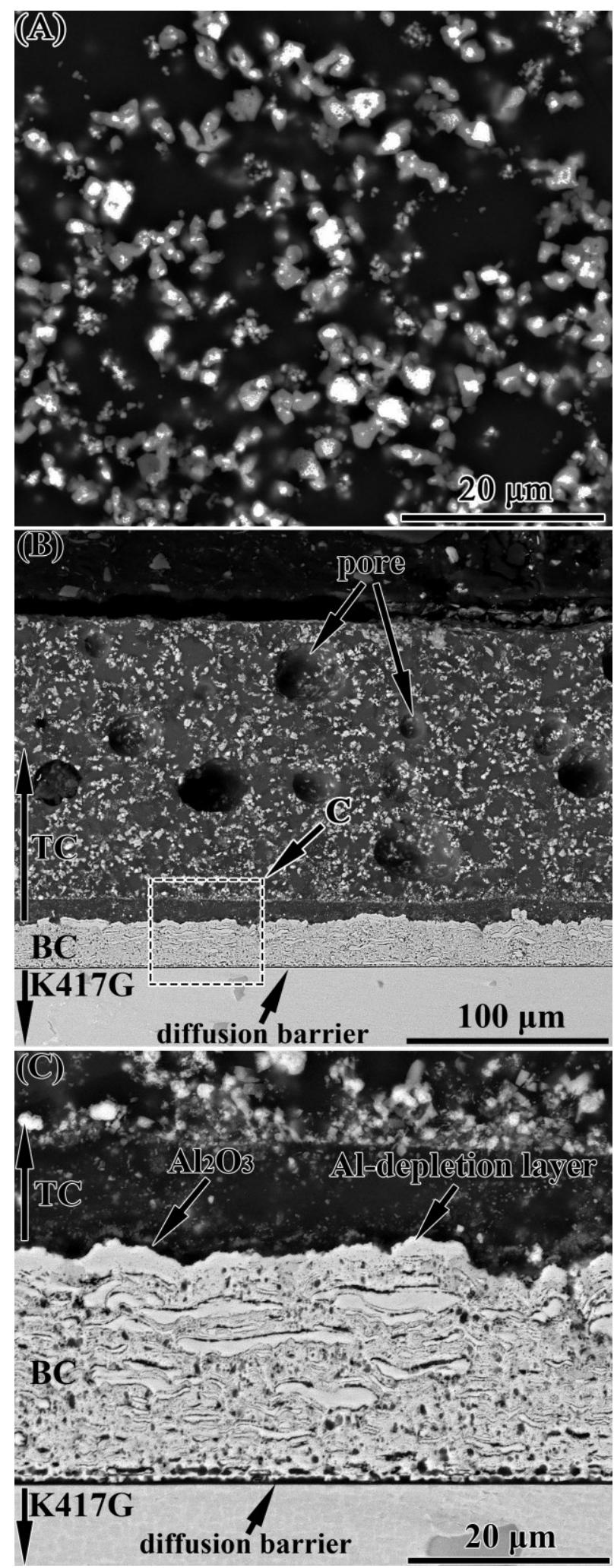


Figure 7 Microstructures of the bond-coat/TGO/top-coat interface after oxidation at 1000 ${ }^{\circ} \mathrm{C}$ for $40 \mathrm{~h}(\mathrm{~A})$ and $100 \mathrm{~h}(\mathrm{~B})$.

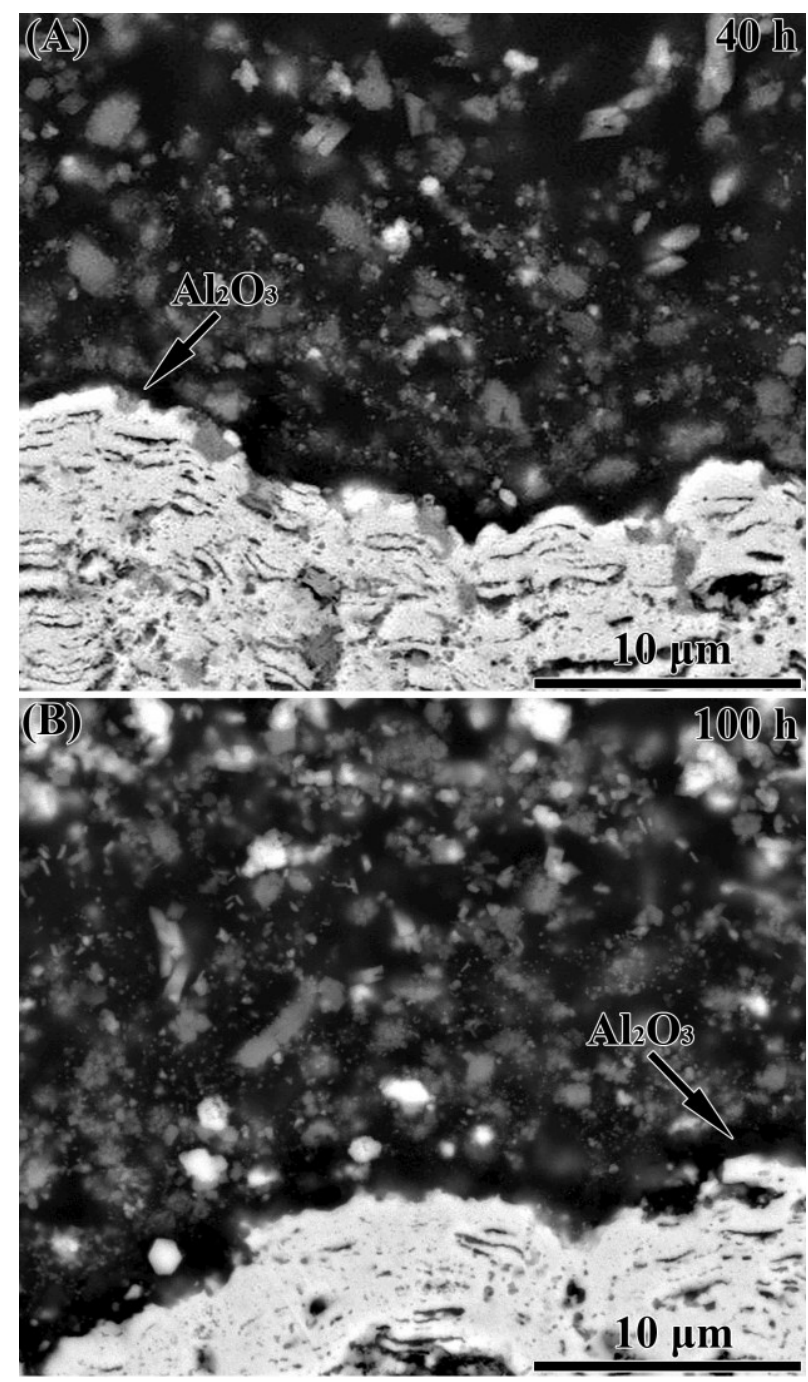


Figure 8 Cross-sectional BSE image and the corresponding element distribution maps of the composite coating after isothermal oxidation at $1000{ }^{\circ} \mathrm{C}$ for $100 \mathrm{~h}$
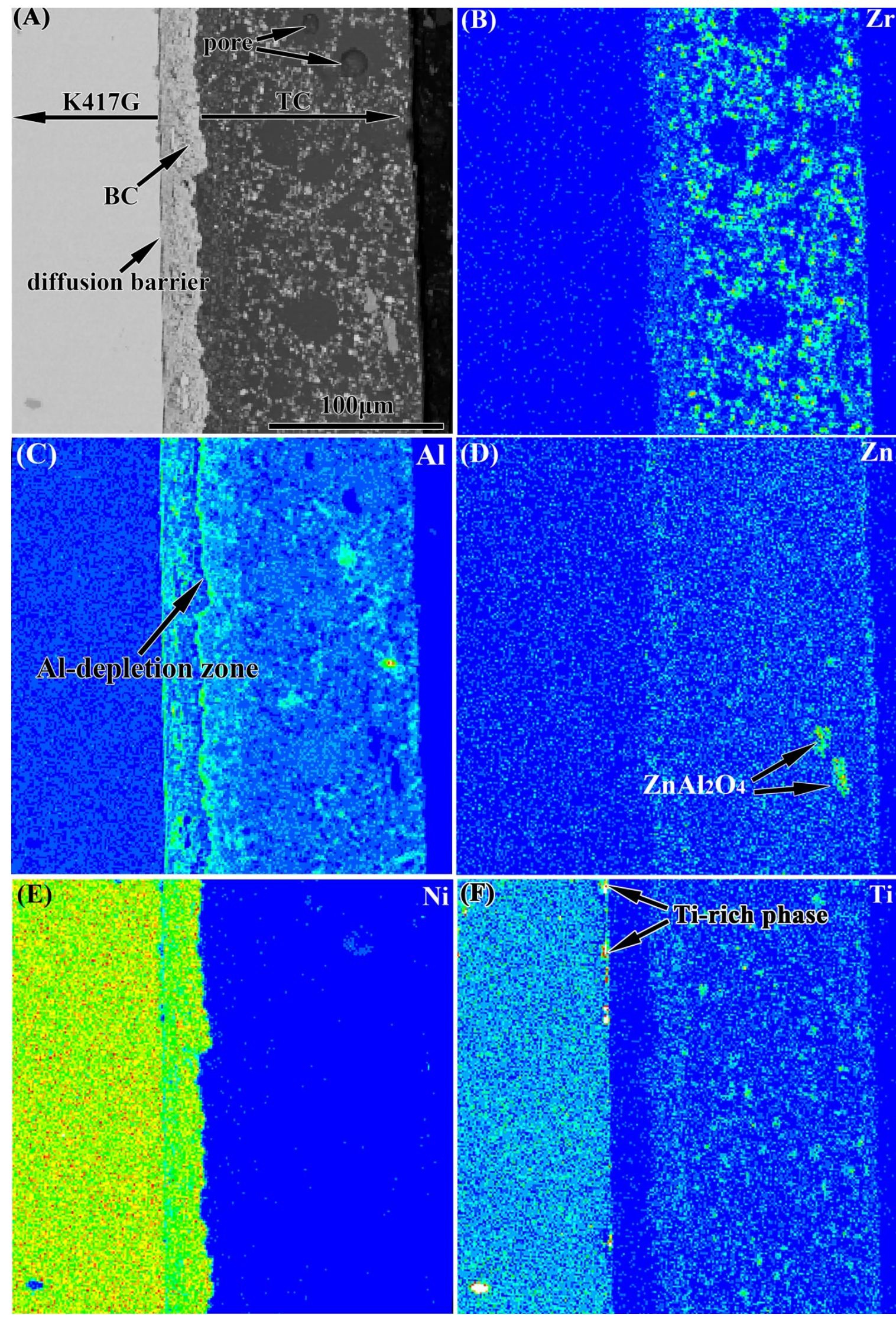
Figure 9 Optical image (A) and cyclic oxidation kinetics of the Ni+CrAlYSiN bond-coat with and without the glass-based composite top-coat at $1000^{\circ} \mathrm{C}$ in static air, the scatter bars show the deviation of maximum/minimum values from the means
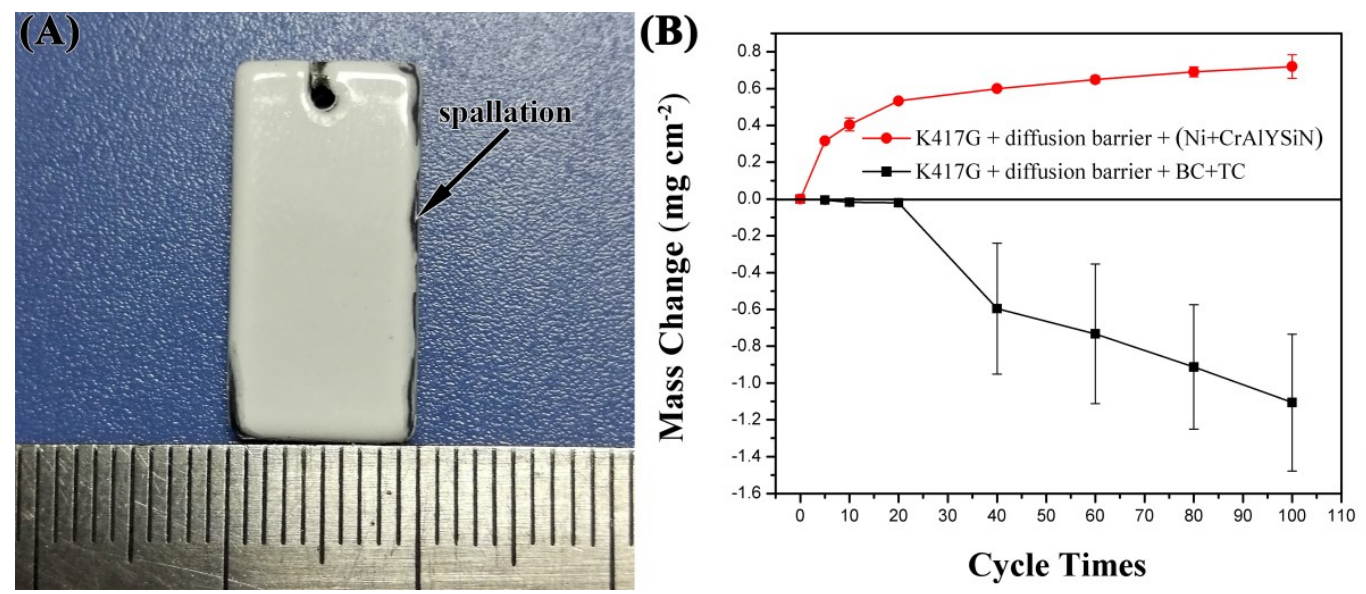

Figure 10 Microstructures of inner part of the top-coat before (A) and after (B) cyclic oxidation at $1000{ }^{\circ} \mathrm{C}$ for 100 times

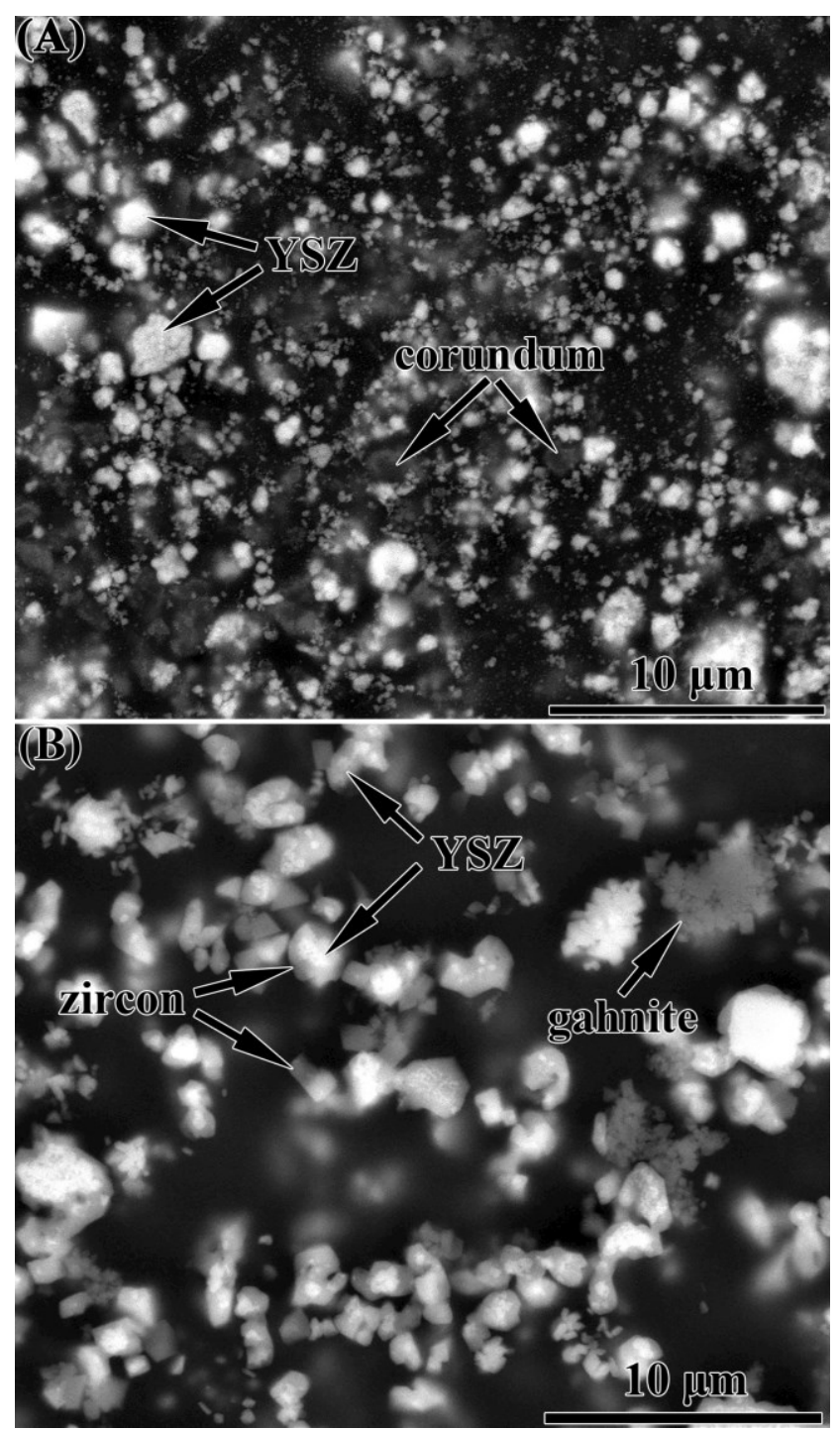


Figure 11 Microstructure of the Ni+CrAlYSiN coating/K417G substrate interface after isothermal oxidation at $1000^{\circ} \mathrm{C}$ for $100 \mathrm{~h}$

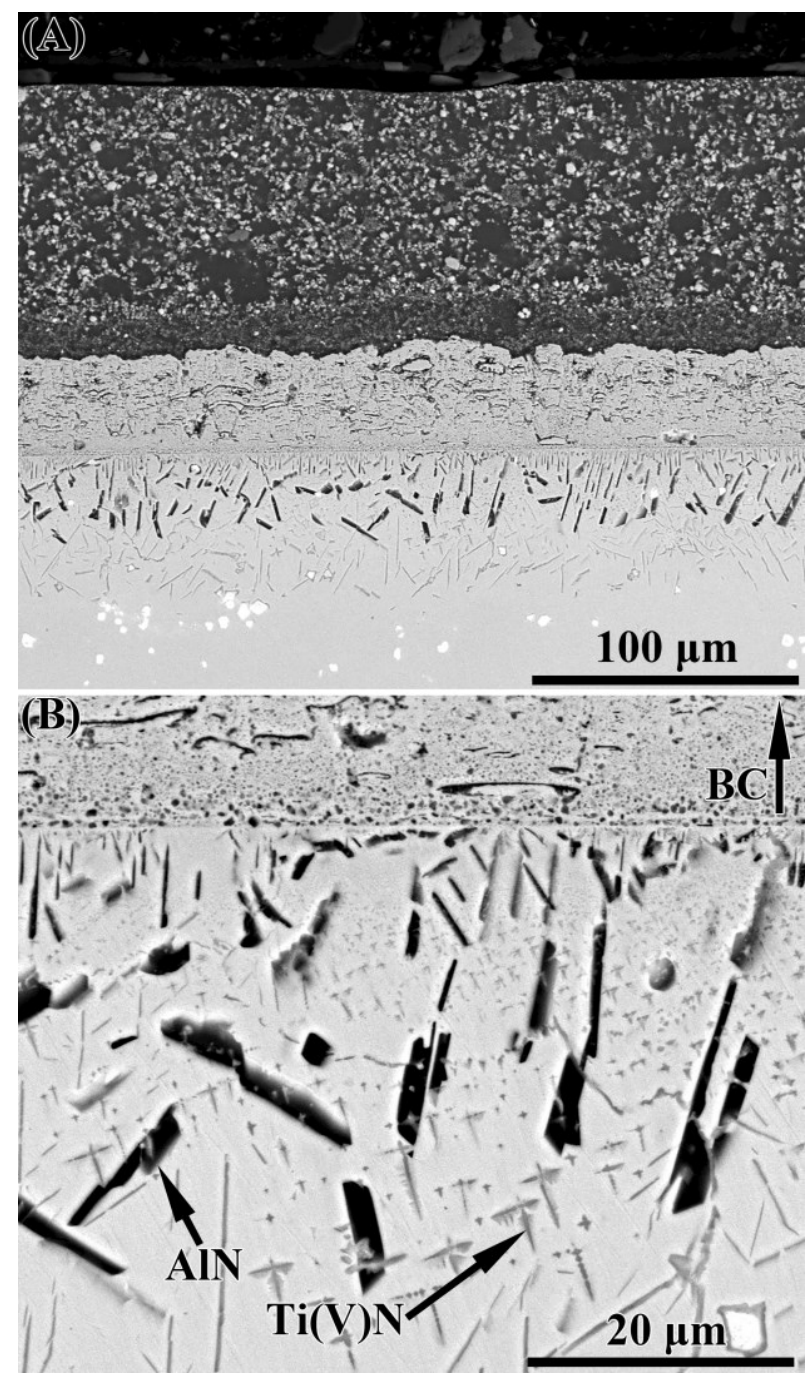

